\title{
Piecing Together Human Adult Comparative Pharmacokinetic Trials and Rodent Studies: What Happens to Drug Clearance in Obesity?
}

\author{
Dion R. Brocks, Hamdah M. Al-Nebaihi, Shamima Parvin and Amel Hamza
}

Faculty of Pharmacy and Pharmaceutical Sciences, University of Alberta, Edmonton, Alberta, Canada

\begin{abstract}
Corresponding author: Dion R. Brocks, Ph.D., Faculty of Pharmacy and Pharmaceutical Sciences, 2-142 H Katz Group Centre for Pharmacy and Health Research, University of Alberta; Edmonton, AB, Canada; T6G 2E1; TEL: (780) 492-2953; email: dbrocks@ualberta.ca
\end{abstract}

Received, November 16, 2021; Revised, December 23, 2021; Accepted, January 1, 2022; Published, January 4, 2022

\begin{abstract}
In many comparative trials examining the effects of adult obesity on pharmacokinetics of drugs, conclusions were made based on values that were either not adjusted to total body weight or adjusted to non-obese body mass (e.g., ideal or lean body weight). In many cases these values were higher in the obese subjects. We have reviewed the data from comparative human trials, and it is apparent that in examining clearance normalization to total body weight (as typically done in studies involving pediatric obese patients), the clearances are often reduced in the obese. We have also reviewed the results of experimental obese versus non-obese rodent models. Those studies have mostly found that the systemic exposures to the same dose per body weight are increased, with obesity-related decreases in clearance. Furthermore, the expression of a number of important drug metabolizing enzymes are reduced in the experimental obese state. There is also evidence that obesity causes increases in the measured mass of eliminating organs such as liver and kidney. Human clearance normalized to total body weight appears to better reflect the underlying changes reported in the expression of protein and functional activity of drug clearance mechanisms.
\end{abstract}

\section{INTRODUCTION}

Since the 1970's there has been a steady rise in the global incidence of obesity, largely attributable to changes in lifestyle (1). These factors include adoption of an excess of sugars and fats in the human diet, and a reduction in societal levels of physical activity. These lifestyle changes have occurred in countries around the globe and have led to serious public health concerns because obesity is associated with increased mortality and morbidity. Serious comorbidities of obesity include Type 2 diabetes mellitus, hyperlipidemia, atherosclerosis, hypertension, heart failure, serious acute cardiovascular events such as stroke and myocardial infarction, depression, arthritis, and cancer. Obesity is a serious risk factor for increased hospitalization and mortality in the face of certain infectious diseases, such as influenza, and notably, Covid-19 (2-5). This being said, obesity unto itself does not indicate a state of ill-health in all people, wherein it has a variable impact on the health of the individual $(6,7)$.

It is common for the obese to be receiving numerous medications for treatment of the comorbidities, even while the patient is being actively treated for the excess weight. A study of UK general practices showed that, over an 18-month period alone, $46 \%$ of obese patients received drug therapy with central nervous system agents, $42 \%$ received antimicrobials, $36 \%$ received cardiovascular drugs and $30 \%$ received agents for musculoskeletal disease (8). Even with the availability of highly effective surgical treatments for morbid obesity (gastric bypass), in Canada wait times are up to two years or more (9). Thus, patients are likely to be receiving these multiple medications for affiliated conditions for a significant duration of time, even once it is deemed that gastric bypass surgery is warranted. In using medications to treat obese patients, it is cogent to take into account the possible influence of the pathophysiological condition posed by obesity on the effectiveness or adverse effects of those medications.

Besides the increases in body mass and adiposity, a number of other biochemical changes may afflict the obese. Adipose possesses characteristics of an endocrine organ and can secrete not only hormones (adipokines) (10), but also proand anti-inflammatory cytokines (11). The adipokines include leptin (involved in regulation of the hypothalamic hunger response, energy 
consumption, sodium reabsorption and blood pressure $(12,13)$ and adiponectin. Adiponectin is the most abundant protein in adipocytes and is involved in oxidation of fatty acids and glucose synthesis (12). Studies in volunteers given recombinant human leptin have shown that its CL is lower in patients with higher BMI (14). Unlike leptin, for which plasma concentrations increase, adiponectin tends to decline in obesity.

In obesity the increase in adipocytes is accompanied by an infiltration of macrophages (15, 16). Macrophages are key to the immune response due to their ability to secrete a number of pro- and anti-inflammatory cytokines. These cytokines include tumor necrosis factor $\alpha(\mathrm{TNF} \alpha)$, interleukin (IL) 6 and C-reactive protein $(12,17)$. In obese mice, up to $40 \%$ of adipose mass may consist of macrophages $(18,19)$. Adipokines are perhaps more specific for obesity than cytokines, which are linked to many inflammatory disorders. However, their effects are not mutually exclusive. For example, adiponectin has both pro- and anti-inflammatory properties $(12,13)$. Because adipose can secrete significant amounts of cytokines, obesity can be considered to be a chronic form of low-grade inflammatory disease.

Pharmacokinetics is intricately linked to measures of drug response and toxicity, as it dictates the concentrations of drug that can come into contact with the receptors for drug action. The possible changes that obesity can have on pharmacokinetics of drugs is important to consider in devising optimal dosage regimens. Pharmacokinetics includes components of drug absorption, distribution, metabolism, and excretion, some of which are also dependent on drug transport proteins.

In this article, the known effects of obesity on pharmacokinetics is reviewed in humans, with a focus on drug clearance (CL). This is followed by an overview of the effects of experimental obesity on the metabolism of drugs in animals, and the models used to study obesity in rodent species.

\section{METHODS}

In searching the literature, PubMed was primarily used to collate data on three main topics pertinent to the review as follows: a. Human data on pharmacokinetics. Search terms included obesity, human, pharmacokinetics, CL and area under the concentration vs. time curve (AUC); b. Rodent models of obesity: Obesity, rodents, rat, mice, and animal model; c. Drug metabolism and pharmacokinetic studies in rodents: Obesity, pharmacokinetics, drug metabolism, cytochrome $\mathrm{P} 450$, rodent, rat, and mice.

In some cases, the papers obtained from this search were used to find other relevant references.

The human data was selected if the paper included a clearly defined obese and non-obese comparison. We restricted the selected papers to adult comparisons. Data was collected for subjects, weight, and BMI, and for CL, volume of distribution (Vd) and terminal phase half-life $\left(t \frac{1}{2}\right)$. Both weight-adjusted and unadjusted estimates of CL and Vd (both divided by bioavailability, F) were sought. In some cases, both weight and height were shown, and if the BMI was not calculated, this was calculated here. In other cases, the standard error of the mean was shown. The corresponding standard deviation (SD) was then calculated as the product of SE and the square root of the number of subjects.

While most papers reported both the total body weight-normalized and non-normalized values of the $\mathrm{Vd}$, many only showed the weight-unadjusted CL. Hence if the mean and the variance were disclosed of the non-weight adjusted CL or Vd values, the weight adjusted values of mean and SD were estimated using the equations outlined by Blumenfield for the quotient of two independent variables (20). To calculate the mean and variance (var) of the weight normalized pharmacokinetic parameter (PKP), the following calculations were applied to the nonweight adjusted PKP:

$$
\begin{gathered}
\text { Mean }\left(\frac{P K P}{w t}\right)=\frac{\text { mean } P K P}{\text { mean } w t} \times\left(1+\frac{\text { var } w t}{\text { mean } w t^{2}}\right) \\
\operatorname{var}\left(\frac{P K P}{w t}\right)=\frac{\text { mean } P K P}{\text { mean } w t} \times\left(\frac{\operatorname{var} P K P}{\text { mean } P K P^{2}}+\frac{\text { var } w t}{\text { mean } w t^{2}}\right)
\end{gathered}
$$

After these calculations were made, var was converted to the SD (square root of var). This provided estimates of mean and SD of most of the weight-normalized values. In turn this allowed for application of the Student's t-test for independent samples and assessment of the significance of the differences between the weight-normalized PKP of the obese and non-obese subjects. The $p$ value was set to $<0.05$. We performed this for all available data sets, even if it was done in the original paper for the weight-normalized data. In Table 1 we show the original results presented in the paper where they did report the weight normalized values. Where they did not, we show the results of our calculations and results showing significance based on our application of the t-test. 


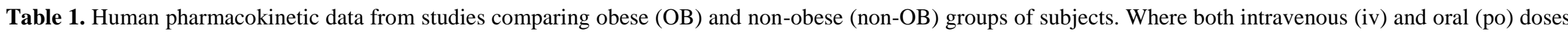

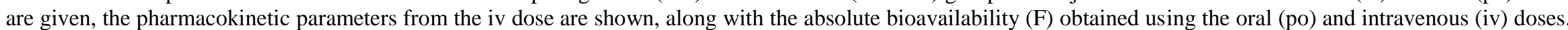

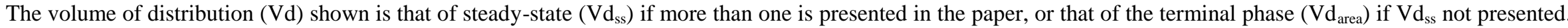

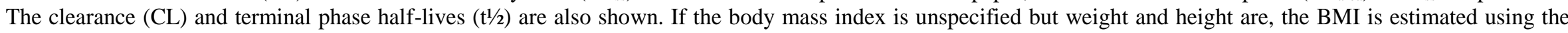

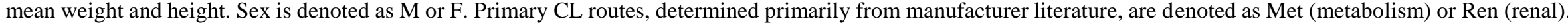

\begin{tabular}{|c|c|c|c|c|c|c|c|c|c|c|c|c|c|c|}
\hline \multirow[b]{2}{*}{$\begin{array}{l}\text { Drug (route and } \\
\text { elimination }\end{array}$} & \multirow{2}{*}{ Group } & \multirow{2}{*}{$\underset{\mathbf{y}}{\text { Age, }}$} & \multirow{2}{*}{$\begin{array}{c}\text { Weight, } \\
\text { kg }\end{array}$} & \multirow{2}{*}{ BMI } & \multirow{2}{*}{$\begin{array}{c}\text { CL/F, } \\
\text { L/h }\end{array}$} & \multirow{2}{*}{$\begin{array}{l}\text { CL/F, } \\
\mathrm{L} / \mathrm{h} / \mathrm{kg}\end{array}$} & \multirow{2}{*}{$\begin{array}{c}\mathbf{V d} / \mathbf{F} \\
\mathbf{L}\end{array}$} & \multirow{2}{*}{$\begin{array}{l}\mathrm{Vd} / \mathrm{F}, \\
\mathrm{L} / \mathrm{kg}\end{array}$} & \multicolumn{5}{|c|}{ Ratio obese to non-obese } & \multirow{2}{*}{$\mathbf{F}_{\text {absolut }}$} \\
\hline & & & & & & & & & $\begin{array}{c}\text { CL/F, } \\
\text { L/h }\end{array}$ & $\begin{array}{l}\text { CL/F, } \\
\mathrm{L} / \mathrm{h} / \mathrm{kg}\end{array}$ & $\begin{array}{c}\mathbf{V d} / \mathbf{F}, \\
\mathrm{L}\end{array}$ & $\begin{array}{l}\mathrm{Vd} / \mathrm{F}, \\
\mathrm{L} / \mathrm{kg}\end{array}$ & $\mathbf{t}^{1 / 2}$ & \\
\hline $\begin{array}{l}\text { Acetaminophen } \\
\text { po (21) Met }\end{array}$ & $\begin{array}{l}\text { OB, } 7 \quad \mathrm{M} \\
14 \mathrm{~F} \\
\text { Non-OB, }\end{array}$ & 36.3 & 103.7 & NA & $22.2^{*}$ & 0.22 & $77.1 *$ & $0.74^{*}$ & 1.43 & 0.85 & 1.28 & 0.74 & 0.89 & NA \\
\hline \multirow{3}{*}{$\begin{array}{l}\text { Acetylsalicylic } \\
\text { acid, iv and po } \\
\text { (22) Met }\end{array}$} & $10 \mathrm{M} 11 \mathrm{~F}$ & 32.9 & 62.6 & NA & 15.5 & 0.26 & 60.1 & 1.0 & & & & & & NA \\
\hline & $\begin{array}{l}\text { OB, } \\
11 \mathrm{M} 9 \mathrm{~F}\end{array}$ & $39 \pm 13$ & $113 \pm 35.3$ & 38.7 & $3.42 \pm 0.3^{*}$ & $\underset{\mathrm{a}}{0.033 \pm 0.0098^{*}}$ & $15.5 \pm 10^{*}$ & $\begin{array}{c}0.151 \pm 0.044 \\
* \mathrm{a}\end{array}$ & \multirow[b]{2}{*}{1.20} & \multirow{2}{*}{0.76} & \multirow[b]{2}{*}{1.19} & \multirow{2}{*}{0.71} & \multirow{2}{*}{1.04} & 1.12 \\
\hline & $\begin{array}{l}\text { Non-OB, } \\
11 \mathrm{M} 9 \mathrm{~F}\end{array}$ & $42 \pm 16$ & $67 \pm 2.2$ & 21.9 & $2.82 \pm 0.24$ & $0.042 \pm 0.0038$ & $13 \pm 0.70$ & $0.194 \pm 0.012$ & & & & & & 1.18 \\
\hline \multirow[t]{2}{*}{$\begin{array}{l}\text { Acyclovir, } \\
\text { (23) Ren }\end{array}$} & $\begin{array}{l}\mathrm{OB} \\
6 \mathrm{M} 6 \mathrm{~F}\end{array}$ & $54.3 \pm 9.6$ & $121 \pm 15.7$ & 45 & $19.4 \pm 5.3^{*}$ & $0.163 \pm 0.056^{* a}$ & $31.8 \pm 9.9$ & $\begin{array}{c}0.264 \pm 0.089 \\
* \mathrm{a}\end{array}$ & \multirow{2}{*}{1.22} & \multirow{2}{*}{0.63} & \multirow{2}{*}{1.42} & \multirow{2}{*}{0.63} & \multirow{2}{*}{0.91} & NA \\
\hline & $\begin{array}{l}\text { Non-OB, } \\
6 \mathrm{M} 6 \mathrm{~F}\end{array}$ & $53.0 \pm 16.3$ & $61.2 \pm 5.1$ & 22.5 & $14.3 \pm 5.4$ & $0.235 \pm 0.090$ & $25.9 \pm 10.4$ & $0.43 \pm 0.17$ & & & & & & NA \\
\hline \multirow[t]{2}{*}{$\begin{array}{l}\text { Alprazolam, } \\
\text { (24) Met }\end{array}$} & $\begin{array}{l}\mathrm{OB} \\
5 \mathrm{M} 7 \mathrm{~F}\end{array}$ & $24-67$ & $112 \pm 41$ & NA & $3.98 \pm 1.45$ & $0.036 \pm 0.014^{* a}$ & $114 \pm 39.5^{*}$ & $1.1 \pm 0.24$ & \multirow{2}{*}{0.75} & \multirow{2}{*}{0.43} & \multirow{2}{*}{1.55} & \multirow{2}{*}{0.97} & \multirow{2}{*}{2.06} & NA \\
\hline & $\begin{array}{l}\text { Non-OB, } \\
5 \mathrm{M} 7 \mathrm{~F}\end{array}$ & $24-68$ & $63.3 \pm 10$ & NA & $5.28 \pm 2.01$ & $0.087 \pm 0.036$ & $73.1 \pm 12.5$ & $1.2 \pm 0.14$ & & & & & & NA \\
\hline \multirow[t]{2}{*}{$\begin{array}{l}\text { Atracurium } \\
\text { (25) Met }\end{array}$} & $\begin{array}{l}\mathrm{OB}, 2 \mathrm{M} 7 \\
\mathrm{~F} \\
\text { Non-OB, } 5\end{array}$ & 54.3 & $\begin{array}{r}\text { M } 156 \pm 6 \\
\text { F } 121 \pm 33 \\
\text { M } 66 \pm 12\end{array}$ & NA & $26.6 \pm 5.22$ & $0.217 \pm 0.062 * a$ & $8.6 \pm 2.1$ & $\begin{array}{c}0.070 \pm 0.022 \\
* \mathrm{a}\end{array}$ & \multirow[t]{2}{*}{1.07} & \multirow[t]{2}{*}{0.53} & 1.01 & 0.48 & 1.01 & NA \\
\hline & M 4 F & 35.6 & F 57士9 & NA & $24.2 \pm 4.5$ & $0.40 \pm 0.099$ & $8.5 \pm 2.1$ & $0.14 \pm 0.041$ & & & & & & NA \\
\hline $\begin{array}{l}\text { Bisoprolol } \\
\text { (26) Ren }\end{array}$ & $\begin{array}{l}\mathrm{OB} \\
8 \mathrm{~F}\end{array}$ & $33 \pm 12$ & $91 \pm 17$ & $38 \pm 5.7$ & $14.8 \pm 1.4^{*}$ & $0.17 \pm 0.034^{* a}$ & $182 \pm 26^{*}$ & $2.0 \pm 0.3^{*}$ & 116 & 065 & 135 & 135 & 113 & NA \\
\hline & $\begin{array}{l}\text { Non-OB, } \\
8 \mathrm{~F}\end{array}$ & $25 \pm 3$ & $51 \pm 4$ & $\begin{array}{l}19.6 \\
\pm 1.3\end{array}$ & $12.8 \pm 2.2$ & $0.25 \pm 0.047$ & $135 \pm 14$ & $2.7 \pm 0.40$ & 1.10 & 0.65 & 1.35 & 1.35 & 1.15 & NA \\
\hline $\begin{array}{l}\text { Caffeine, } \\
\text { po(27) Met }\end{array}$ & $\begin{array}{l}\mathrm{OB}, 4 \mathrm{M} \\
11 \mathrm{~F}\end{array}$ & $32 \pm 8$ & $109 \pm 32$ & $39 \pm 13$ & $8.10 \pm 3.36$ & $0.081 \pm 0.04$ & $69.9 \pm 23.6^{*}$ & $0.653 \pm 0.29$ & 1.21 & 0.71 & 1.60 & 0.94 & 1.31 & NA \\
\hline & $\begin{array}{l}\text { Non-OB, } \\
7 \text { M } 16 \text { F }\end{array}$ & $28 \pm 4$ & $64 \pm 14.39$ & $22 \pm 2.9$ & $6.7 \pm 3.5$ & $0.11 \pm 0.06$ & $43.6 \pm 13.4$ & $0.72 \pm 0.26$ & 1.21 & 0.11 & 1.00 & 0.94 & 1.51 & NA \\
\hline $\begin{array}{l}\text { Carbamazepine, } \\
\text { po (28) Met }\end{array}$ & $\begin{array}{l}\mathrm{OB} \\
5 \mathrm{M} 13 \mathrm{~F}\end{array}$ & $32.3 \pm 10.4$ & $111 \pm 19.9$ & 38.8 & $1.2 \pm 0.31$ & $0.011 \pm 0.003^{* a}$ & $98.4 \pm 26.9 *$ & $0.91 \pm 0.29$ & 0.86 & 0.49 & 1.62 & 0.93 & 1.92 & NA \\
\hline & $\begin{array}{l}\text { Non-OB, } \\
3 \mathrm{M} 10 \mathrm{~F}\end{array}$ & $30.8 \pm 8.9$ & $63.2 \pm 8.3$ & 22.4 & $1.4 \pm 0.28$ & $0.022 \pm 0.004$ & $61 \pm 8.5$ & $0.98 \pm 0.18$ & & & & & & NA \\
\hline $\begin{array}{l}\text { Cefoxitin, } \\
\text { (29) Ren }\end{array}$ & $\begin{array}{l}\mathrm{OB}, \\
2 \mathrm{M} 12 \mathrm{~F}\end{array}$ & $52 \pm 8$ & $126 \pm 29$ & $43 \pm 10$ & $11.8 \pm 2.58$ & $0.099 \pm 0.029^{* a}$ & $18 \pm 5^{*}$ & $0.14 \pm 0.04 *$ & 0.76 & 0.41 & 1.64 & 0.74 & 1.33 & NA \\
\hline & $\begin{array}{l}\text { Non-OB, } \\
6 \mathrm{M} 7 \mathrm{~F}\end{array}$ & $28 \pm 12$ & $60 \pm 10$ & $21 \pm 2$ & $14.4 \pm 6.06$ & $0.247 \pm 0.11$ & $11 \pm 5$ & $0.19 \pm 0.06$ & & & & & & NA \\
\hline
\end{tabular}

Table 1. continues... 


\begin{tabular}{|c|c|c|c|c|c|c|c|c|c|c|c|c|c|c|c|}
\hline \multirow{2}{*}{$\begin{array}{l}\text { Cimetidine, } \\
\text { (30) Ren }\end{array}$} & iv & $\begin{array}{l}\mathrm{OB} \\
2 \mathrm{M} 4 \mathrm{~F}\end{array}$ & $28 \pm 4$ & $140 \pm 24$ & 59 & $69 \pm 16^{*}$ & $0.51 \pm 0.14$ & $82 \pm 24$ & $0.60 \pm 0.20^{* a}$ & \multirow[b]{2}{*}{1.80} & \multirow[b]{2}{*}{0.80} & \multirow[b]{2}{*}{0.99} & \multirow[b]{2}{*}{0.44} & \multirow[b]{2}{*}{0.63} & NA \\
\hline & & $2 \mathrm{M} 4 \mathrm{~F}$ & $28 \pm 4$ & $62 \pm 7$ & 20.4 & $38 \pm 6.8$ & $0.62 \pm 0.13$ & $84 \pm 13$ & $1.37 \pm 0.26$ & & & & & & NA \\
\hline $\begin{array}{l}\text { Ciprofloxacin, } \\
\text { (31) Met }\end{array}$ & iv & $\begin{array}{l}\mathrm{OB} \\
17 \mathrm{M}\end{array}$ & $29.2 \pm 7.5$ & $111 \pm 29$ & $36.4 \pm 3.9$ & $54 \pm 9.6^{*}$ & $0.52 \pm 0.15^{* a}$ & $269 \pm 51.6^{*}$ & $2.59 \pm 0.79$ & \multirow[b]{2}{*}{1.21} & \multirow[b]{2}{*}{0.78} & \multirow[b]{2}{*}{1.23} & \multirow[b]{2}{*}{0.80} & \multirow[b]{2}{*}{1.07} & NA \\
\hline & & $\begin{array}{l}\text { Non-OB, } \\
11 \mathrm{M}\end{array}$ & $25.0 \pm 5.1$ & $72 \pm 9.9$ & $23.3 \pm 2.4$ & $44.6 \pm 7.23$ & $0.63 \pm 0.13$ & $219 \pm 35.8$ & $3.1 \pm 0.65$ & & & & & & NA \\
\hline \multirow[t]{2}{*}{$\begin{array}{l}\text { Clorazepate, } \\
\text { (32) Ren }\end{array}$} & po & $\begin{array}{l}\mathrm{OB} \\
8 \mathrm{M} 4 \mathrm{~F}\end{array}$ & 33 & 105 & NA & 0.79 & 0.0075 & $159^{*}$ & $1.51^{*}$ & \multirow[b]{2}{*}{0.99} & \multirow[b]{2}{*}{0.63} & \multirow[b]{2}{*}{2.52} & \multirow[b]{2}{*}{1.61} & \multirow[b]{2}{*}{2.70} & NA \\
\hline & & $\begin{array}{l}\text { Non-OB, } \\
7 \text { M } 5 \text { F }\end{array}$ & 33 & 67 & NA & 0.80 & 0.0119 & 63 & 0.940 & & & & & & NA \\
\hline \multirow[t]{2}{*}{$\begin{array}{l}\text { Cyclosporine } \\
\text { iv(33) Met }\end{array}$} & A & $\begin{array}{l}\mathrm{OB}, \\
6 \mathrm{M} 4 \mathrm{~F} \\
\text { Non-OB, }\end{array}$ & $48.7 \pm 13.6$ & $89.7 \pm 10.8$ & NA & $43.0 \pm 21.5$ & $0.48 \pm 0.24 *$ & $228.7 \pm 76.2$ & $2.55 \pm 0.85^{*}$ & \multirow[t]{2}{*}{0.87} & \multirow[t]{2}{*}{0.63} & \multirow[t]{2}{*}{0.77} & \multirow[t]{2}{*}{0.56} & \multirow[t]{2}{*}{0.94} & 0.33 \\
\hline & & $15 \mathrm{M} 20 \mathrm{~F}$ & $46.2 \pm 14.2$ & $65.1 \pm 11.5$ & NA & $49.3 \pm 22.2$ & $0.76 \pm 0.34$ & $296 \pm 176$ & $4.54 \pm 2.7$ & & & & & & 0.31 \\
\hline \multirow[t]{2}{*}{$\begin{array}{l}\text { Daptomycin, } \\
\text { (34) Ren }\end{array}$} & iv & $\begin{array}{l}\mathrm{OB} \\
7 \mathrm{~F}\end{array}$ & $36.8 \pm 11$ & $114.3 \pm 15.8$ & $46.2 \pm 5.5$ & $0.82 \pm 0.21$ & $\begin{array}{c}0.0073 \pm 0.0021 \\
*\end{array}$ & $10.0 \pm 2.04$ & $0.09 \pm 0.01 *$ & \multirow{2}{*}{1.12} & \multirow{2}{*}{0.59} & \multirow{2}{*}{1.31} & \multirow{2}{*}{0.69} & \multirow{2}{*}{1.12} & NA \\
\hline & & $\begin{array}{l}\text { Non-OB, } \\
7 \mathrm{~F}\end{array}$ & $29.1 \pm 12$ & $58.8 \pm 6.2$ & $21.8 \pm 1.9$ & $0.73 \pm 0.15$ & $0.011 \pm 0.0024$ & $7.69 \pm 1.5$ & $0.13 \pm 0.02$ & & & & & & NA \\
\hline \multirow{2}{*}{\multicolumn{2}{|c|}{$\begin{array}{l}\text { Dexfenfluramine, } \\
\text { iv and po (35) } \\
\text { Met }\end{array}$}} & $\begin{array}{l}\mathrm{OB} \\
5 \mathrm{M} 5 \mathrm{~F}\end{array}$ & $29 \pm 9$ & 95.1 & $32.2 \pm 2.9$ & $43.9 \pm 21$ & 0.462 & $970 \pm 393^{*}$ & $10.2 \pm 3.2$ & & & & & & 0.61 \\
\hline & & $\begin{array}{l}\text { Non-OB, } \\
5 \mathrm{M} 5 \mathrm{~F}\end{array}$ & $27.5 \pm 6$ & 59.2 & $20.8 \pm 2.0$ & $37.7 \pm 11$ & 0.751 & $669 \pm 140$ & $11.3 \pm 2.2$ & 1.16 & 0.62 & 1.45 & 0.90 & 1.32 & 0.69 \\
\hline $\begin{array}{l}\text { Dexmedetomid } \\
\text { e, iv (36) Met }\end{array}$ & & $\begin{array}{l}\mathrm{OB}, \\
8 \mathrm{M} 4 \mathrm{~F}\end{array}$ & $29.8 \pm 7.8$ & $125 \pm 10.4$ & 45.4 & $58.6 \pm 10.66^{*}$ & $0.472 \pm 0.094^{* a}$ & $310 \pm 63.08^{*}$ & $2.5 \pm 0.054$ & 131 & 0.73 & 190 & 104 & 1.42 & NA \\
\hline & & $\begin{array}{l}\text { Non-OB, } \\
8 \mathrm{M} 4 \mathrm{~F}\end{array}$ & $35.8 \pm 5.4$ & $69.9 \pm 6.1$ & 23.8 & $44.9 \pm 9$ & $0.647 \pm 0.14$ & $164 \pm 41.91$ & $2.36 \pm 0.63$ & & & & & & NA \\
\hline $\begin{array}{l}\text { Digoxin, } \\
\text { (37) Ren }\end{array}$ & iv & OB, & 34 & $100 \pm 36.8$ & NA & $19.7 \pm 4.9$ & $0.22 \pm 0.087$ & $981 \pm 301$ & $11.1 \pm 4.7$ & 1.17 & 0.84 & 1.04 & 0.74 & 0.86 & NA \\
\hline & & $\begin{array}{l}\text { Non-OB, } \\
7 \text { M } 6 \text { F }\end{array}$ & 32 & $64.6 \pm 10.5$ & NA & $16.7 \pm 5.2$ & $0.27 \pm 0.091$ & $937 \pm 397$ & $14.9 \pm 6.6$ & & & & & & NA \\
\hline $\begin{array}{l}\text { Ertapenem, } \\
\text { (38) Met }\end{array}$ & iv & $\begin{array}{l}\text { OB, } \\
5 \mathrm{M} 5 \mathrm{~F}\end{array}$ & $35.9 \pm 5.1$ & $127 \pm 12.5$ & 43 & $1.91 \pm 0.25$ & $0.015 \pm 0.002 *$ & $7.18 \pm 1.1$ & $0.057 \pm 0.009$ & 1.05 & 0.79 & 1.19 & 0.90 & 1.14 & NA \\
\hline & & $\begin{array}{l}\mathrm{OB}, \\
5 \mathrm{M} 5 \mathrm{~F}\end{array}$ & $41.8 \pm 5.1$ & $96.0 \pm 9.1$ & 33.4 & $1.82 \pm 0.29$ & $0.019 \pm 0.003 *$ & $6.04 \pm 1.2$ & $0.063 \pm 0.01$ & 1.14 & 0.79 & 1.17 & 0.81 & 1.03 & NA \\
\hline & & $\begin{array}{l}\text { Non-OB, } \\
5 \text { M } 5 \text { F }\end{array}$ & $34.1 \pm 8.4$ & $66.7 \pm 9.6$ & 22.5 & $1.60 \pm 0.27$ & $0.024 \pm 0.004$ & $5.15 \pm 0.5$ & $0.078 \pm 0.008$ & & & & & & NA \\
\hline $\begin{array}{l}\text { Glipizide, } \\
\text { (39) Met }\end{array}$ & po & $\begin{array}{l}\mathrm{OB} \\
7 \mathrm{M} 5 \mathrm{~F}\end{array}$ & $53.5 \pm 8.5$ & $95.5 \pm 17.2$ & NA & $2.3 \pm 1$ & $0.025 \pm 0.011$ & $19.5 \pm 4.4$ & $0.22 \pm 9.059$ & 1.15 & 1.00 & 1.13 & 0.98 & 0.96 & NA \\
\hline & & $\begin{array}{l}\text { Non-OB, } \\
6 \mathrm{M} 2 \mathrm{~F}\end{array}$ & $57.8 \pm 11.7$ & $80.8 \pm 9.9$ & NA & $2.0 \pm 1$ & $0.022 \pm 0.011$ & $17.2 \pm 4.3$ & $0.19 \pm 0.052$ & & & & & & NA \\
\hline $\begin{array}{l}\text { Glyburide, } \\
\text { (40) Met }\end{array}$ & po & $\begin{array}{l}\mathrm{OB}, \\
4 \mathrm{M} 8 \mathrm{~F}\end{array}$ & $55.3 \pm 12.6$ & $100 \pm 22.8$ & $36.0 \pm 9.1$ & $3.26 \pm 2.19$ & $0.03 \pm 0.023$ & $47.0 \pm 47$ & $0.49 \pm 0.48$ & & & & & & NA \\
\hline & & $\begin{array}{l}\text { Non-OB, } \\
5 \text { M } 3 \text { F }\end{array}$ & $60.8 \pm 13.0$ & $73.3 \pm 7.2$ & $24.5 \pm 2.0$ & $3.1 \pm 1.98$ & $0.043 \pm 0.27$ & $56.8 \pm 60.3$ & $0.78 \pm 0.83$ & 1.05 & 0.77 & 0.83 & 0.61 & 0.68 & NA \\
\hline
\end{tabular}

Table 1. continues... 


\begin{tabular}{|c|c|c|c|c|c|c|c|c|c|c|c|c|c|c|}
\hline \multirow[t]{2}{*}{$\begin{array}{l}\text { Ibuprofen, } \\
\text { (41) Met }\end{array}$} & $\begin{array}{l}\mathrm{OB}, \\
6 \mathrm{M} 5 \mathrm{~F}\end{array}$ & $35 \pm 13$ & $114 \pm 36.48$ & 38.6 & $4.99 \pm 1.15^{*}$ & $0.048 \pm 0.017$ & $14.9 \pm 2.98 *$ & $0.144 \pm 0.049$ & \multirow{2}{*}{1.41} & \multirow{2}{*}{0.75} & \multirow{2}{*}{1.38} & \multirow{2}{*}{0.74} & \multirow{2}{*}{0.93} & \multirow{2}{*}{$\begin{array}{l}\text { NA } \\
\text { NA }\end{array}$} \\
\hline & $\begin{array}{l}\text { Non-OB, } \\
6 \mathrm{M} 5 \mathrm{~F}\end{array}$ & $36 \pm 13$ & $61 \pm 9.9$ & 20.7 & $3.55 \pm 0.815$ & $0.060 \pm 0.018$ & $10.8 \pm 2.32$ & $0.181 \pm 0.048$ & & & & & & \\
\hline \multirow[t]{2}{*}{$\begin{array}{l}\text { Ketoprofen, } \\
\text { (42) Met }\end{array}$} & $\begin{array}{l}\mathrm{OB} \\
8 \mathrm{M} 13 \mathrm{~F}\end{array}$ & $57 \pm 14$ & $91 \pm 10$ & 33.7 & $5.22 \pm 1.63$ & $0.057 \pm 0.027$ & $7.92 \pm 5.19^{* a}$ & $\begin{array}{c}0.087 \pm 0.047 \\
*\end{array}$ & \multirow[b]{2}{*}{1.31} & \multirow[b]{2}{*}{0.94} & \multirow{2}{*}{0.60} & \multirow{2}{*}{0.43} & \multirow[b]{2}{*}{0.43} & NA \\
\hline & $\begin{array}{l}\text { Non-OB, } \\
6 \mathrm{M} 14 \mathrm{~F}\end{array}$ & $52 \pm 15$ & $65 \pm 7$ & 23.8 & $3.98 \pm 2.41$ & $0.061 \pm 0.040$ & $13.2 \pm 8.39$ & $0.203 \pm 0.129$ & & & & & & NA \\
\hline \multirow[t]{3}{*}{$\begin{array}{l}\text { Levonorgestrel, } \\
\text { po (43) Met }\end{array}$} & $\begin{array}{l}\text { Morbid OB } \\
10 \mathrm{~F} \\
\mathrm{OB}\end{array}$ & 30 & 120.7 & 46.6 & $7.7 \pm 1.09^{*}$ & $0.0638^{\mathrm{c}}$ & $466 \pm 39.6^{*}$ & $3.86^{\mathrm{c}}$ & 1.72 & 0.78 & 2.88 & 1.31 & 1.56 & NA \\
\hline & $10 \mathrm{~F}$ & 24.4 & 93 & 34.4 & $8.51 \pm 3.71^{*}$ & $0.0915^{\mathrm{c}}$ & $405 \pm 140.2$ & $4.35^{\mathrm{c}}$ & \multirow[t]{2}{*}{1.90} & \multirow[t]{2}{*}{1.12} & \multirow[t]{2}{*}{2.50} & \multirow[t]{2}{*}{1.47} & \multirow[t]{2}{*}{1.38} & NA \\
\hline & $\begin{array}{l}\text { Non-OB } \\
10 \mathrm{~F}\end{array}$ & 26.3 & 54.9 & 22 & $4.48 \pm 0.07$ & 0.0816 & $162 \pm 54.6^{*}$ & 2.95 & & & & & & NA \\
\hline \multirow[t]{2}{*}{$\begin{array}{l}\text { Lithium, po (44) } \\
\text { Ren }\end{array}$} & $\begin{array}{l}\mathrm{OB}, \\
3 \mathrm{M} 7 \mathrm{~F}\end{array}$ & $34.7 \pm 5.7$ & $110 \pm 28.6$ & 38.9 & $2.034 \pm 0.42 *$ & $0.0197 \pm 0.0061$ & $46.0 \pm 9.46$ & $\begin{array}{c}0.418 \pm 0.086 \\
*\end{array}$ & \multirow[t]{2}{*}{1.47} & \multirow[t]{2}{*}{0.89} & \multirow[t]{2}{*}{1.10} & \multirow[t]{2}{*}{0.67} & \multirow[t]{2}{*}{0.73} & NA \\
\hline & $\begin{array}{l}\text { Non-OB, } \\
2 \mathrm{M} 6 \mathrm{~F}\end{array}$ & $33 \pm 7.7$ & $63.1 \pm 6.6$ & 21.9 & $1.38 \pm 0.372$ & $0.022 \pm 0.0063$ & $41.8 \pm 9.97$ & $0.662 \pm 0.158$ & & & & & & NA \\
\hline \multirow[t]{2}{*}{$\begin{array}{l}\text { Lidocaine, } \\
\text { (45) Met }\end{array}$} & $\begin{array}{l}\mathrm{OB} \\
14 \mathrm{M}\end{array}$ & $35 \pm 11.2$ & $124 \pm 30$ & 39 & $85.6 \pm 26.3$ & $0.731 \pm 0.268^{* a}$ & $325 \pm 108.5^{*}$ & $2.77 \pm 1.08$ & \multirow{2}{*}{1.06} & \multirow{2}{*}{0.59} & \multirow{2}{*}{1.75} & \multirow{2}{*}{0.97} & 166 & NA \\
\hline & $\begin{array}{l}\text { Non-OB, } \\
19 \mathrm{M}\end{array}$ & $31 \pm 8.7$ & $69 \pm 4.4$ & 22 & $80.8 \pm 22.5$ & $1.17 \pm 0.334$ & $186 \pm 52.3$ & $2.70 \pm 0.777$ & & & & & 1.00 & NA \\
\hline $\begin{array}{l}\text { Lidocaine, } \\
\text { (45) Met }\end{array}$ & $\begin{array}{l}\mathrm{OB} \\
11 \mathrm{~F}\end{array}$ & $32 \pm 9.9$ & $96 \pm 20$ & 36 & $65.3 \pm 16.51$ & $0.71 \pm 0.22^{* a}$ & $264 \pm 66.3^{*}$ & $2.89 \pm 0.90$ & 0.94 & 058 & 126 & 078 & 142 & NA \\
\hline & $\begin{array}{l}\text { Non-OB, } \\
12 \mathrm{~F}\end{array}$ & $30 \pm 6.9$ & $59 \pm 6.9$ & 21 & $69.7 \pm 17.45$ & $1.01 \pm 0.26$ & $209 \pm 51.9$ & $3.04 \pm 0.78$ & 0.94 & 0.00 & 1.20 & 0.10 & 1.42 & NA \\
\hline $\begin{array}{l}\text { Lorazepam } \\
\text { (46) }\end{array}$ & $\begin{array}{l}\mathrm{OB}, 6 \mathrm{M} 8 \\
\mathrm{~F} \\
\text { Non-OB, } 5\end{array}$ & $(23-66)$ & $111.7 \pm 37.8$ & NA & $6.12 \pm 2.29^{*}$ & $0.0548 \pm 0.027$ & $131 \pm 31$ & $1.25 \pm 0.37$ & 1.62 & 0.91 & 1.69 & 1.02 & 1.11 & NA \\
\hline Lurasidone, po & $\begin{array}{l}\text { M 9 F } \\
\text { OB, }\end{array}$ & $(23-66)$ & $62.5 \pm 8.23$ & NA & $3.77 \pm 1.21$ & $0.060 \pm 0.016$ & $77.2 \pm 12.3$ & $1.23 \pm 0.15$ & & & & & & NA \\
\hline (47) Met & $\begin{array}{l}6 \mathrm{M} 7 \mathrm{~F} \\
\text { Non-OB, }\end{array}$ & $33 \pm 7$ & $140 \pm 32$ & $49.3 \pm 9.6$ & $330^{\mathrm{d}}$ & $2.36^{\mathrm{d}}$ & $37.1^{\mathrm{d}}$ & $0.26^{\mathrm{d}}$ & 1.04 & 0.50 & 0.59 & 0.28 & 1.16 & NA \\
\hline & $6 \mathrm{M} 5 \mathrm{~F}$ & $34 \pm 8$ & $67.9 \pm 9.1$ & $23.1 \pm 1.8$ & $317^{d}$ & $4.67^{\mathrm{d}}$ & $63.3^{\mathrm{d}}$ & $0.93^{\mathrm{d}}$ & & & & & & NA \\
\hline $\begin{array}{l}\text { Methylprednisolo } \\
\text { ne succinate, iv }\end{array}$ & $\mathrm{OB}, 6 \mathrm{M}$ & $27.5 \pm 4.1$ & $116 \pm 10.1$ & 34.1 & $161 \pm 41$ & $1.4 \pm 0.37$ & $46 \pm 9.4^{*}$ & $0.40 \pm 0.088$ & 144 & 0.99 & 149 & 103 & 0.63 & NA \\
\hline (48) Met & $\begin{array}{l}\text { Non-OB, } \\
6 \mathrm{M}\end{array}$ & $24.7 \pm 4.3$ & $79.9 \pm 6.2$ & 24.7 & $108 \pm 43$ & $1.36 \pm 0.55$ & $31.4 \pm 11.8$ & $0.40 \pm 0.15$ & & & & & 0.03 & NA \\
\hline $\begin{array}{l}\text { Midazolam, iv } \\
\text { and po (49) Met }\end{array}$ & $\begin{array}{l}\mathrm{OB}, \\
13 \mathrm{M} 7 \mathrm{~F}\end{array}$ & $35.6 \pm 10.7$ & $117 \pm 34$ & NA & $28.3 \pm 10.2$ & $0.25 \pm 0.09^{*}$ & $311 \pm 120.7 *$ & $2.67 \pm 0.72 *$ & 0.89 & 0.50 & 2.73 & 1.54 & 2.62 & 0.42 \\
\hline & $\begin{array}{l}\text { Non-OB, } \\
\text { 13M } 7 \text { F }\end{array}$ & $37.5 \pm 14.8$ & $65.7 \pm 6.7$ & NA & $31.8 \pm 9.1$ & $0.48 \pm 0.12$ & $114 \pm 45$ & $1.74 \pm 0.49$ & & & & & & 0.40 \\
\hline $\begin{array}{l}\text { Nitrazepam, } \\
\text { (50) Met }\end{array}$ & $\begin{array}{l}\text { OB, } \\
7 \mathrm{M} 7 \mathrm{~F}\end{array}$ & $35 \pm 15$ & $107 \pm 34$ & NA & $6.06 \pm 2.8^{*}$ & $0.056 \pm 0.013$ & $290 \pm 168^{*}$ & $2.62 \pm 0.64$ & & 087 & & & & NA \\
\hline & $\begin{array}{l}\text { Non-OB, } \\
7 \text { M } 7 \text { F }\end{array}$ & $36 \pm 16$ & $63 \pm 11.2$ & NA & $4.0 \pm 1.1$ & $0.064 \pm 0.016$ & $140 \pm 45$ & $2.22 \pm 0.71$ & 1.02 & 0.01 & 2.12 & 1.10 & 1.40 & NA \\
\hline
\end{tabular}

Table 1. continues... 


\begin{tabular}{|c|c|c|c|c|c|c|c|c|c|c|c|c|c|c|c|}
\hline \multirow{2}{*}{\multicolumn{2}{|c|}{$\begin{array}{l}\text { Oseltamivir, } \\
\text { (51) Met }\end{array}$}} & $\begin{array}{l}\mathrm{OB} \\
2 \mathrm{M} 8 \mathrm{~F}\end{array}$ & 39 & 125 & 46 & $840 *$ & 6.80 & 2320 & 20.7 & \multirow[b]{2}{*}{1.45} & \multirow[b]{2}{*}{0.79} & \multirow[b]{2}{*}{1.39} & \multirow[b]{2}{*}{0.78} & \multirow[b]{2}{*}{1.11} & \multirow{2}{*}{$\begin{array}{l}\text { NA } \\
\text { NA }\end{array}$} \\
\hline & & $\begin{array}{l}\text { Non-OB, } \\
2 \mathrm{M} 8 \mathrm{~F}\end{array}$ & 29 & 69 & 24 & 580 & 8.60 & 1670 & 26.7 & & & & & & \\
\hline $\begin{array}{l}\text { Oxazepam p } \\
\text { (46) Met }\end{array}$ & po & $\begin{array}{l}\mathrm{OB}, 5 \mathrm{M} 6 \\
\mathrm{~F} \\
\text { Non-OB, } 5\end{array}$ & $(23-66)$ & $115 \pm 13$ & NA & $9.41 \pm 4.55^{*}$ & $0.083 \pm 0.034 *$ & $97.1 \pm 44.1^{*}$ & $0.84 \pm 0.27 *$ & 3.11 & 1.62 & 2.53 & 1.35 & 0.87 & NA \\
\hline \multirow{3}{*}{\multicolumn{2}{|c|}{$\begin{array}{l}\text { Phenytoin, } \\
\text { (52) Met }\end{array}$}} & M $6 \mathrm{~F}$ & $(23-66)$ & $60 \pm 8.6$ & NA & $3.02 \pm 1.19$ & $0.049 \pm 0.016$ & $38.4 \pm 15.6$ & $0.62 \pm 0.17$ & & & & & & NA \\
\hline & & $\begin{array}{l}\mathrm{OB}, \\
11 \mathrm{M} 3 \mathrm{~F}\end{array}$ & $37 \pm 15$ & $124 \pm 37.4$ & NA & $3.54 \pm 2.24$ & $0.031 \pm 0.020$ & $82.2 \pm 29.6^{*}$ & $0.72 \pm 0.31$ & \multirow{2}{*}{1.51} & \multirow{2}{*}{0.70} & \multirow{2}{*}{2.04} & \multirow[b]{2}{*}{0.94} & \multirow[b]{2}{*}{1.91} & NA \\
\hline & & $\begin{array}{l}\text { Non-OB, } \\
8 \mathrm{M} 2 \mathrm{~F}\end{array}$ & $35 \pm 9.5$ & $67 \pm 9.5$ & NA & $2.34 \pm 0.57$ & $0.036 \pm 0.098$ & $40.2 \pm 6.0$ & $0.61 \pm 0.12$ & & & & & & NA \\
\hline \multirow[t]{3}{*}{$\begin{array}{l}\text { Piperacillin, } \\
\text { (53) Ren }\end{array}$} & iv & $\begin{array}{l}\text { Morbid } \\
\text { OB, } \\
4 \text { M } 8 \text { F }\end{array}$ & $54 \pm 15$ & $143 \pm 34$ & 55 & $19.7 \pm 8.6^{*}$ & $0.138 \pm 0.068$ & NA & NA & 1.84 & 1.04 & NA & NA & NA & NA \\
\hline & & $\begin{array}{l}\mathrm{OB} \\
6 \mathrm{M} 6 \mathrm{~F}\end{array}$ & $47 \pm 12$ & $90 \pm 10$ & 33 & $11.1 \pm 3$ & $0.125 \pm 0.036$ & NA & NA & \multirow[t]{2}{*}{1.04} & \multirow[t]{2}{*}{0.93} & \multirow[t]{2}{*}{ NA } & \multirow[t]{2}{*}{ NA } & \multirow[t]{2}{*}{ NA } & NA \\
\hline & & $\begin{array}{l}\text { Non-OB, } \\
11 \mathrm{M} 2 \mathrm{~F}\end{array}$ & $48 \pm 17$ & $81 \pm 11$ & 27 & $10.7 \pm 5$ & $0.135 \pm 0.064$ & NA & NA & & & & & & NA \\
\hline \multirow{2}{*}{\multicolumn{2}{|c|}{$\begin{array}{l}\text { Posaconazole, po } \\
\text { (47) Met }\end{array}$}} & $\begin{array}{l}\mathrm{OB}, \\
6 \mathrm{M} 7 \mathrm{~F} \\
\text { Non-OB, }\end{array}$ & $33 \pm 7$ & $140 \pm 32$ & $49.3 \pm 9.6$ & $10.5 \pm 5.46^{*}$ & $0.079 \pm 0.04$ & $792^{\mathrm{b}}$ & 5.68 & \multirow[t]{2}{*}{1.72} & \multirow[t]{2}{*}{0.84} & \multirow[t]{2}{*}{2.91} & \multirow[t]{2}{*}{1.41} & \multirow[t]{2}{*}{1.69} & NA \\
\hline & & $6 \mathrm{M} 5 \mathrm{~F}$ & $34 \pm 8$ & $67.9 \pm 9.1$ & $23.1 \pm 1.8$ & $6.1 \pm 4.26$ & $0.091 \pm 0.064$ & $272^{\mathrm{b}}$ & 4.03 & & & & & & NA \\
\hline \multirow{2}{*}{\multicolumn{2}{|c|}{$\begin{array}{l}\text { Prednisolone, iv } \\
\text { (54) Met }\end{array}$}} & $\begin{array}{l}\mathrm{OB} \\
8 \mathrm{M}\end{array}$ & $24 \pm 5$ & $121 \pm 20$ & 37.8 & $11.1 \pm 1.9^{*}$ & $0.094 \pm 0.022$ & $44.1 \pm 10.6$ & $0.347 \pm 0.106$ & \multirow{2}{*}{1.35} & \multirow{2}{*}{0.82} & \multirow{2}{*}{1.20} & 0.69 & 0.91 & NA \\
\hline & & $\begin{array}{l}\text { Non-OB, } \\
4 \mathrm{M}\end{array}$ & $29 \pm 3$ & $72 \pm 7$ & 23.8 & $8.25 \pm 0.92$ & $0.116 \pm 0.017$ & $36.7 \pm 7.9$ & $0.514 \pm 0.120$ & & & & & & NA \\
\hline $\begin{array}{l}\text { Procainamide, i } \\
\text { (55) Met }\end{array}$ & iv & $\begin{array}{l}\mathrm{OB}, \\
2 \mathrm{M} 5 \mathrm{~F}\end{array}$ & $33 \pm 7$ & $100 \pm 17.3$ & $\begin{array}{c}34.3 \pm 3.8 \\
6^{*}\end{array}$ & $51.7 \pm 9.17$ & $0.53 \pm 0.13$ & $158 \pm 33$ & $1.63 \pm 0.43^{* a}$ & 1.23 & 0.84 & 1.05 & 2.57 & 0.81 & NA \\
\hline & & $\begin{array}{l}\text { Non-OB, } \\
3 \mathrm{M} 4 \mathrm{~F}\end{array}$ & $27 \pm 3$ & $68.4 \pm 11.5$ & $\begin{array}{c}22.7 \pm 2.7 \\
3\end{array}$ & $41.9 \pm 13.6$ & $0.63 \pm 0.22$ & $150 \pm 26$ & $2.25 \pm 0.53$ & & 0.04 & $1.0 \mathrm{~J}$ & 2.01 & 0.01 & NA \\
\hline $\begin{array}{l}\text { Propofol } \\
\text { (56) Met }\end{array}$ & & $\begin{array}{l}\mathrm{OB}, \\
5 \mathrm{M} 6 \mathrm{~F}\end{array}$ & $30.4 \pm 7.5$ & $131 \pm 27.2$ & $47.8 \pm 8.0$ & 549 & 4.36 & 111 & 0.85 & 2.31 & 1.19 & 1.52 & 0.76 & 5.42 & NA \\
\hline & & $\begin{array}{l}\text { OB, } \\
4 \mathrm{M} 8 \mathrm{~F}\end{array}$ & $30.4 \pm 7.5$ & $124 \pm 26.7$ & $44.6 \pm 8.8$ & 600 & 4.78 & 98.7 & 0.796 & 2.43 & 1.31 & 1.36 & 0.71 & 6.79 & NA \\
\hline & & $\begin{array}{l}\text { Non-OB, } \\
3 \mathrm{M} 3 \mathrm{~F}\end{array}$ & $30.4 \pm 10.8$ & $65.3 \pm 3.1$ & $\begin{array}{c}23.8 \pm 0.4 \\
1\end{array}$ & 247 & 3.63 & 72.6 & 1.12 & & & & & & NA \\
\hline $\begin{array}{l}\text { Propranolol, i } \\
\text { and po (57) Met }\end{array}$ & iv & $\begin{array}{l}\mathrm{OB} \\
3 \mathrm{M} 3 \mathrm{~F}\end{array}$ & $33 \pm 6$ & $137 \pm 35.8$ & 46.2 & $46.8 \pm 2.9$ & $0.37 \pm 0.092^{* a}$ & $339 \pm 53.8^{*}$ & $2.6 \pm 0.76$ & 100 & 050 & 173 & 087 & 167 & 0.35 \\
\hline & & $\begin{array}{l}\text { Non-OB, } \\
3 \text { M } 3 \text { F }\end{array}$ & $33 \pm 6$ & $66.8 \pm 11.3$ & 22.5 & $46.8 \pm 1.46$ & $0.721 \pm 0.121$ & $198 \pm 21.2$ & $3.0 \pm 0.59$ & 1.00 & 0.00 & 1.13 & 0.01 & 1.07 & 0.27 \\
\hline $\begin{array}{l}\text { Ranitidine, } \\
\text { (58) Ren }\end{array}$ & iv & $\begin{array}{l}\mathrm{OB} \\
10 \mathrm{~F}\end{array}$ & $34.5 \pm 5.1$ & $104 \pm 10.4$ & NA & $34.5 \pm 6.9$ & $0.34 \pm 0.074^{* a}$ & $83.3 \pm 21.9$ & $0.81 \pm 0.23^{* a}$ & 1.10 & 0.56 & 1.08 & 0.55 & 1.13 & NA \\
\hline & & $\begin{array}{l}\text { Non-OB, } \\
10 \mathrm{~F}\end{array}$ & $35.6 \pm 5.8$ & $54.8 \pm 4.5$ & NA & $32.3 \pm 6.1$ & $0.59 \pm 0.12$ & $79.5 \pm 14$ & $1.5 \pm 0.28$ & & & & & & NA \\
\hline $\begin{array}{l}\text { Thiopental, } \\
\text { (59) Met }\end{array}$ & iv & $\begin{array}{l}\mathrm{OB}, 2 \mathrm{M} 5 \\
\mathrm{~F} \\
\text { Non-OB, } 0\end{array}$ & $33 \pm 7$ & $137.9 \pm 41.3$ & 48.9 & $25.0 \pm 14.9^{*}$ & $0.18 \pm 0.0812$ & $648 \pm 63$ & $4.7 \pm 2.7^{*}$ & 2.11 & 0.86 & $8.10^{\mathrm{e}}$ & 3.37 & 4.42 & NA \\
\hline & & M 8 F & $34.5 \pm 6.4$ & $57.4 \pm 5$ & 21.3 & $11.9 \pm 3.7$ & $0.21 \pm 0.06$ & $80.4 \pm 26$ & $1.4 \pm 0.46$ & & & & & & NA \\
\hline
\end{tabular}

Table 1. continues... 


\begin{tabular}{|c|c|c|c|c|c|c|c|c|c|c|c|c|c|c|}
\hline \multirow[t]{4}{*}{$\begin{array}{l}\text { Tramadol, } \\
\text { (60) Met }\end{array}$} & $\begin{array}{l}\mathrm{OB}, \\
10 \mathrm{M} 2 \mathrm{~F} \\
\text { OB/diabeti }\end{array}$ & $57 \pm 8$ & $100 \pm 17$ & 33 & $120 \pm 40$ & $1.2 \pm 0.4$ & $620 \pm 310$ & $6.2 \pm 3.1$ & 1.31 & 0.88 & 1.01 & 0.67 & 0.69 & NA \\
\hline & $\begin{array}{l}\mathrm{c}, \\
7 \mathrm{M} 2 \mathrm{~F} \\
\text { Overweigh }\end{array}$ & $64 \pm 10$ & $89 \pm 14$ & 33 & $125 \pm 45$ & $1.4 \pm 0.5$ & $641 \pm 267$ & $7.2 \pm 3.0$ & 1.00 & 0.75 & 1.04 & 0.78 & 0.91 & NA \\
\hline & $13 \mathrm{M} 3 \mathrm{~F}$ & $63 \pm 11$ & $84 \pm 17$ & 27 & $88 \pm 42$ & $1.4 \pm 0.5$ & $630 \pm 328$ & $7.5 \pm 3.9$ & 0.82 & 0.88 & 0.77 & 0.82 & 0.72 & NA \\
\hline & $\begin{array}{l}\text { Non-OB, } \\
8 \mathrm{M}, 4 \mathrm{~F}\end{array}$ & $61 \pm 14$ & $67 \pm 8$ & 22 & $107 \pm 47$ & $1.6 \pm 0.7$ & $616 \pm 322$ & $9.2 \pm 4.8$ & & & & & & NA \\
\hline \multirow[t]{2}{*}{$\begin{array}{l}\text { Trazodone, iv } \\
\text { and po (61) Met }\end{array}$} & $\begin{array}{l}\text { OB, } \\
12 \mathrm{M} 11 \mathrm{~F}\end{array}$ & $39 \pm 19$ & $112 \pm 34$ & 38.3 & $8.76 \pm 2.88$ & $0.082 \pm 0.029 *$ & $162 \pm 71.9^{*}$ & $1.43 \pm 0.33^{*}$ & \multirow{2}{*}{1.07} & \multirow{2}{*}{0.62} & \multirow{2}{*}{2.42} & \multirow{2}{*}{1.40} & \multirow{2}{*}{2.25} & 0.84 \\
\hline & $\begin{array}{l}\text { Non-OB, } \\
12 \mathrm{M} 11 \mathrm{~F}\end{array}$ & $40 \pm 19$ & $65 \pm 9.6$ & 22.2 & $8.16 \pm 2.3$ & $0.13 \pm 0.037$ & $67 \pm 19.18$ & $1.04 \pm 0.33$ & & & & & & 0.81 \\
\hline \multirow[t]{2}{*}{$\begin{array}{l}\text { Triazolam, } \\
\text { (24) Met }\end{array}$} & $\begin{array}{l}\mathrm{OB} \\
6 \mathrm{M} 3 \mathrm{~F}\end{array}$ & $24-67$ & $120 \pm 45$ & NA & $20.4 \pm 7.83^{*}$ & $0.19 \pm 0.091^{* a}$ & $117 \pm 48$ & $1.11 \pm 0.54 * \mathrm{a}$ & \multirow{2}{*}{0.67} & \multirow{2}{*}{0.39} & \multirow{2}{*}{1.01} & \multirow{2}{*}{0.61} & \multirow{2}{*}{1.61} & NA \\
\hline & $\begin{array}{l}\text { Non-OB, } \\
5 \mathrm{M} 4 \mathrm{~F}\end{array}$ & $24-67$ & $64.2 \pm 3.9$ & NA & $31.9 \pm 6.86$ & $0.50 \pm 0.11$ & $116 \pm 35$ & $1.81 \pm 0.56$ & & & & & & NA \\
\hline \multirow[t]{2}{*}{$\begin{array}{l}\text { Vancomycin, } \\
\text { (62) Ren }\end{array}$} & $\begin{array}{l}\text { OB, } \\
13 \text { M } 37 \mathrm{~F}\end{array}$ & $59.3 \pm 14.0$ & $106 \pm 20.8$ & $36.7 \pm 6.4$ & $4.70 \pm 1.3$ & $0.046 \pm 0.015^{* a}$ & $74.4 \pm 14.5^{*}$ & $0.73 \pm 0.19$ & \multirow{2}{*}{1.18} & \multirow{2}{*}{0.72} & \multirow{2}{*}{1.52} & \multirow{2}{*}{1.00} & \multirow{2}{*}{0.77} & \multirow[t]{2}{*}{ NA } \\
\hline & $\begin{array}{l}\text { Non-OB, } \\
54 \text { M } 17 \text { F }\end{array}$ & $59.6 \pm 15.4$ & $71.9 \pm 13.3$ & $23.9 \pm 3.1$ & $4.40 \pm 1.4$ & $0.063 \pm 0.023$ & $50.4 \pm 9.3$ & $0.72 \pm 0.18$ & & & & & & \\
\hline \multirow[t]{2}{*}{$\begin{array}{l}\text { Vancomycin, } \\
\text { (63) Ren }\end{array}$} & $\begin{array}{l}\mathrm{OB}, \\
14 \mathrm{M} 10 \mathrm{~F}\end{array}$ & $41 \pm 7$ & $165 \pm 46$ & NA & $11.8 \pm 4.62 *$ & $0.072 \pm 0.012$ & $52 \pm 13$ & $0.32 \pm 0.05^{*}$ & \multirow{2}{*}{2.56} & \multirow{2}{*}{1.05} & \multirow{2}{*}{1.13} & \multirow{2}{*}{0.47} & \multirow{2}{*}{0.46} & NA \\
\hline & $\begin{array}{l}\text { Non-OB, } \\
14 \mathrm{M} 10 \mathrm{~F}\end{array}$ & $41 \pm 8$ & $68 \pm 6$ & NA & $4.62 \pm 1.32$ & $0.066 \pm 0.018$ & $46 \pm 16$ & $0.68 \pm 0.24$ & & & & & & NA \\
\hline \multirow{3}{*}{$\begin{array}{l}\text { Verapamil iv (64) } \\
\text { Met }\end{array}$} & Obese, $7 \mathrm{M}$ & & & & & & & & \multirow{3}{*}{1.07} & \multirow{3}{*}{0.62} & \multirow{3}{*}{2.37} & & & \\
\hline & $\begin{array}{l}5 \mathrm{~F} \\
\text { Non-obese, }\end{array}$ & $39 \pm 10$ & $127 \pm 27$ & $41.7 \pm 12$ & $80.3 \pm 37.4$ & $0.72 \pm 0.37^{* a}$ & $713 \pm 333 *$ & $6.4 \pm 3.4$ & & & & \multirow[t]{2}{*}{1.38} & \multirow[t]{2}{*}{2.81} & NA \\
\hline & $7 \mathrm{M} 4 \mathrm{~F}$ & $37 \pm 13$ & $74 \pm 13$ & $24.3 \pm 3$ & $75.0 \pm 29.3$ & $1.11 \pm 0.44$ & $301 \pm 33$ & $4.5 \pm 0.62$ & & & & & & NA \\
\hline \multirow[t]{2}{*}{$\begin{array}{l}\text { Vortioxetine, po } \\
\text { (65) Met }\end{array}$} & $\begin{array}{l}\text { OB, } \\
3 \mathrm{M} 13 \mathrm{~F} \\
\text { Non-OB, }\end{array}$ & $34 \pm 8$ & $119 \pm 22.4$ & $\begin{array}{l}41.8 \pm 7.0 \\
23.0 \pm 2 .\end{array}$ & $48.5 \pm 19.9$ & $0.43 \pm 0.21$ & $5480^{\mathrm{b}}$ & $46.2^{\mathrm{b}}$ & 0.90 & 0.51 & 1.32 & 0.75 & 1.48 & NA \\
\hline & $6 \mathrm{M} 8 \mathrm{~F}$ & $28 \pm 10$ & $67.7 \pm 9.7$ & 0 & $54.2 \pm 27.0$ & $0.80 \pm 0.40$ & $4147^{\mathrm{b}}$ & $61.3^{\mathrm{b}}$ & & & & & & NA \\
\hline
\end{tabular}

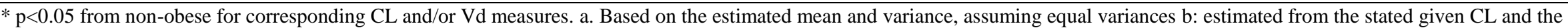
half-life Insufficient data for estimation of variance or t-test. c: authors provided no information on this parameter, or insufficient data to allow for statistical analysis (variance not provided) d. Estimated from dose, AUC and half-lives presented in the paper. Insufficient data for estimation of variance or t-test. e. Omitted in Figures 2 and 3 (high outlier). NA: Not available 
Because the values of the individual study subjects were not available, this approach makes the assumption of equal variance in the obese and nonobese groups. These data are highlighted with a superscript symbol in summary Table 1 . While this this is an assumption, it was observed that in every case where these estimates of mean and variance were determined and t-test applied (for either weightadjusted or unadjusted PKP), the statistical results of significance matched those that were reported in the original paper for both weight adjusted and nonadjusted PKP of CL and Vd.

Bar and whisker plots were constructed using Microsoft Excel for Windows (Redmond, WA), and show the minimum, maximum, median, quartiles and mean, including outliers.

For animal studies, the relative expressions of enzyme or transporter function were sought in obese versus non-obese animals and restricted to translational outcomes of immunoblots for protein concentration or activity using chemical probes.

\section{PHARMACOKINETICS OF DRUGS IN HUMAN OBESITY}

\section{General considerations}

Amongst clinical pharmacologists, the effects of obesity on pharmacokinetics have attracted attention particularly since the $1970 \mathrm{~s}$. It is of note that many of the important formative papers involving human trials were authored by D.R. Abernethy, D.J. Greenblatt and colleagues. Our search and summary of comparative trials of obese vs. non-obese subjects is shown in Table 1.

Volume of distribution. The $\mathrm{Vd}$ is dependent upon factors such as relative affinities of drug binding to proteins in both the blood and tissues, and degree of lipophilicity of the drug within blood. For lipophilic drugs it might be expected that the Vd would increase with increased adiposity, whereas those with hydrophilic propensity would not be expected to change. Drugs that bind to lipoproteins might be expected to have a reduced unbound fraction in plasma $\left(f_{u, p}\right)$ or whole blood $\left(f_{u, b}\right)$ in obesity, because hyperlipidemia is a known comorbidity. This could tend to decrease the $\mathrm{Vd}$ of such lipoprotein-bound drugs in obesity. The $\mathrm{Vd}$ if based on nonintravascular data and unknown bioavailability $(\mathrm{F})$ is abbreviated as $\mathrm{Vd} / \mathrm{F}$; note for intravascular doses $\mathrm{F}$ is assumed to be 1 . Wherever possible the steady-state $\mathrm{Vd}$ was sought $\left(\mathrm{Vd}_{\mathrm{ss}}\right)$ from the retrieved literature.

In determining drug dosage, the $\mathrm{Vd}$ can have a direct impact on loading dose calculations. Body metrics, which could directly affect the Vd of a drug, have been a main focus of changes in pharmacokinetics in obesity.

Determinants of drug clearance. The pharmacokinetic parameter of CL (for oral data, $\mathrm{CL} / \mathrm{F})$ is the main indicator of the speed of elimination of drug from the blood fluids, and it is a key determinant of the dosing rate to be used to achieve steady-state concentrations. It is a summative value of all of the organs responsible for drug removal from the blood fluids, and the two main organs responsible are the liver and the kidney. Hepatic CL according to the well-stirred model is depicted as:

$$
C L_{h}=Q_{h} \times E=Q_{h} \times \frac{f_{u, b} \times C L_{\text {int }}^{\prime}}{Q_{h}+f_{u, b} \times C L_{\text {int }}^{\prime}}
$$

Where $Q_{H}$ is hepatic blood flow (portal vein + hepatic arterial flows), $C L_{\text {int }}^{\prime}$ is intrinsic clearance of unbound drug, and $f_{u, b}$ is the unbound fraction in blood. The $C L_{\text {int }}$ of the drug is dependent on factors such as the maximal rate of metabolism of the drug by all of the responsible hepatic drug metabolizing enzymes, the net affinity of the drug for those enzymes, and the ability of the drug to reach those enzymes, which is a function of diffusion and drug transport protein function. Changes in any of these factors can lead to a change in drug CL by the liver.

The CL of drug by the kidney is dependent on three main processes, filtration CL, CL by tubular secretion $\left(C L_{\text {secretion }}\right)$, and the fraction of drug reabsorbed from the tubules $\left(f_{\text {reabsorbed }}\right)$. Most drugs are freely filtered by the glomerulus and the CL of drugs by glomerular filtration is dependent upon the following:

$$
\begin{gathered}
C L_{\text {renal }}=\left[\left(f_{u, p} \times G F R\right)+C L_{\text {secretion }}\right] \\
\times\left(1-f_{\text {reabsorbed }}\right)
\end{gathered}
$$

Where filtration $C L$ is the product of the glomerular filtration rate $(G F R)$ by the $f_{u, p}$. The other main mechanism leading to an increase in $C L_{\text {renal }}$ is $C L_{\text {secretion, }}$ which is highly dependent on transport proteins on the basolateral and brush border membranes of tubular epithelial cells. This represents an entry point for drug from the blood to the forming urine. A process that works against $C L_{\text {renal }}$ is tubular reabsorption, which is thought to be mostly a reverse diffusional process of drug returning to the tubular capillary blood from the tubular lumen (although transporters are implicated for some drugs). Renal tubular metabolism can also contribute to $C L_{\text {renal }}$, 
although this is typically insignificant compared to the other processes. Thus, any obesity-related changes in plasma protein binding, renal blood flow, expression and affinities of drug transport proteins, urine $\mathrm{pH}$ and expression and affinity of drug for metabolizing enzymes could change $C L_{\text {renal }}$. All of these mechanisms are potentially alterable in the face of a medical condition such as obesity.

The terminal phase half-life $\left(t^{1 / 2}\right)$ of a drug is dependent upon both the Vd and the CL of the drug, and thus can be changed in response to changes in $\mathrm{CL}$ or Vd. It is of use in determining the dosing interval with repeated doses and for determining when blood samples are likely to represent steadystate concentrations.

\section{Observed effects of human obesity}

Influence on volume of distribution. Our search for human trials examining the comparative effects of obesity on pharmacokinetics in adults is shown in Table 1 (22-24, 26-45, 47-58, 60-63, 65). Figure 1 shows the relationships between the $\mathrm{Vd} / \mathrm{F}$ and the $\log \mathrm{P}$ of the drugs presented in Table 1. While there is a suggestion of an increase in $\mathrm{Vd} / \mathrm{F}$ when based on both weight adjusted and unadjusted values, it is not a consistent finding. This underscores that the $\mathrm{Vd}$ is not simply a function of lipophilicity, but more importantly, elements of plasma and tissue protein binding. If the body weight-unadjusted values are examined, the $\mathrm{Vd} / \mathrm{F}$ in obesity appears generally elevated (Table 1, Figure 2). However, when viewed on a total-weight-adjusted basis, $\mathrm{Vd} / \mathrm{F}$ appears mostly lower in the obese. It might be expected that increased $\mathrm{Vd} / \mathrm{F}$ is more likely to occur when the drug is more lipophilic and possesses a higher oil to water coefficient $(\log \mathrm{P})$.

Our analysis (Figure 1) differed somewhat from that reported in another recent paper (66), which reported that over a narrower range of $\log \mathrm{P}(0$ to 2.5) there was a more consistent increase in the total and unbound $\mathrm{Vd} / \mathrm{F}$ in obese compared to nonobese; only $\mathrm{Vd} / \mathrm{F}$ unadjusted for body weight was assessed.

In some cases, specific attention to the effects of body weight and BMI have been described for specific drugs. One example involved the $\mathrm{Vd}$ of ethanol in subjects over a spectrum of BMI from low to obese, where the weight-normalized Vd was found in a sex-specific manner to change according to weight. Two regression equations were determined, which showed that as the BMI increased, there was a linear decrease in the $\mathrm{Vd}(67)$.
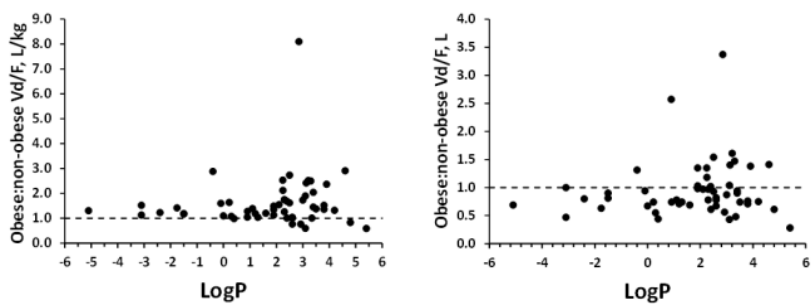

Figure 1. Relationship between the physicochemical property of $\log \mathrm{P}$ and the $\mathrm{Vd} / \mathrm{F}$ ratios of mean obese to respective mean non-obese values from the studies shown in Table 1. The dashed horizontal lines depict a ratio of one.

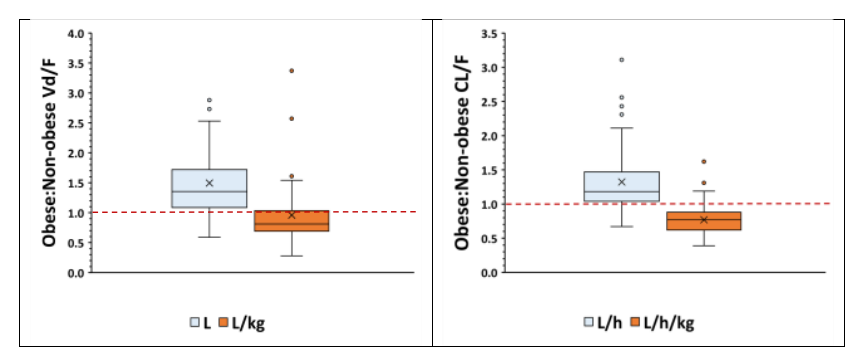

Figure 2. Relative $\mathrm{Vd} / \mathrm{F}$ and $\mathrm{CL} / \mathrm{F}$ of drugs in human obese compared to non-obese subjects. The obese to nonobese ratios are shown as both the total body weight unadjusted and adjusted parameters. Data is based on mean values from the summary provided of comparative studies shown in Table 1. The dashed horizontal lines depict a ratio of one.

On drug clearance in humans. Expectations of effect of obesity on drug clearance. Obesity-related alterations in drug CL might be expectedly less predictable than that of $\mathrm{Vd}$, because of the involvements of transporter protein and drug metabolizing enzymes in drug elimination. The infiltration of adipose tissue by macrophages $(15,16)$ leads to higher plasma concentrations of pro- and anti-inflammatory cytokines. It is known that some of these elevated cytokine concentrations coincide with decreased expressions of some drug metabolizing enzymes and drug transport proteins. For example, inflammation in rats was associated with suppression in hepatic P-glycoprotein (P-gp) and gastrointestinal segments $(69,70)$. Some of the pro-inflammatory cytokines secreted by adipose, including TNFa and IL6, may also selectively decrease hepatic CYP, including CYP3A4 and 2C8 (71). After exposing human hepatocytes to TNF $\alpha$ and IL6, reductions were seen in several drug transporter (72). This decrease in expression increased with higher cytokine concentrations. The exposure to IL6 also led to reduced expression of some $\mathrm{ABC}$ transporters (72). These findings were largely in line in rat livers after with exposure to exposed to 
bacterial lipopolysaccharide (73). Mild inflammation induced by dosing of bacterial lipopolysaccharide to healthy volunteers likewise was associated with decreases in CL of antipyrine, hexobarbital and theophylline (74), probably due to a decrease in CYP expression. Increases in circulating tumor necrosis factor (TNF $\alpha$ ), interleukin 6 (IL6), C reactive protein and $\alpha 1$ acid glycoprotein were all seen. Thus, given that adiposity is a form of chronic inflammation, and that inflammation is prone to cause decreases in the expression of some drug metabolizing enzymes, one might expect a decrease in CL in the obese.

Findings from review of comparative trials. From Table 1 the data of CL/F were compiled in different ways. In terms of the overall $\mathrm{CL} / \mathrm{F}$, most studies reported and performed statistical testing for only the values unadjusted for body weight. When the total body weight-normalized values of $\mathrm{CL} / \mathrm{F}$ are compared, however, there is a general reduction in the value in the obese vs. the non-obese. In many of these cases, the difference is significant (Table 1). The relative values of the obese to non-obese CL/F ratios were mostly well above one for the unadjusted values, but less than one for the adjusted values (Table 1, Figure 2).

Drugs vary in their fraction of CL attributable to metabolism and renal excretion. To see how this compares for metabolized and renally excreted drugs, the data were summarized in Figure 3 for the pharmacokinetic parameter ratios of obese to nonobese subjects, stratified by the relative contributions of renal and metabolic processes towards CL. Both weight-adjusted and unadjusted parameters of $\mathrm{Vd} / \mathrm{F}$ and $\mathrm{CL} / \mathrm{F}$ overlapped for high and low levels of metabolism.

Drugs with higher rates of CL are typically more dependent on organ blood flows than other factors, such as $\mathrm{CL}^{\prime}$ int or $f_{u, b}$ of the drug. When stratified by relative rates of $\mathrm{CL} / \mathrm{F}$ (based on nonobese subjects), there seemed to be no effect on the ratios of obese to non-obese for weight adjusted or unadjusted CL/F (Figure 4).

Some authors have included in their comparative studies an assessment of the relative unbound fractions of the study drugs in their obese and non-obese study subjects. Most of these studies found no significant difference in blood fluid unbound fraction between the obese and non-obese. These included acetylsalicylic acid (22), phenytoin (52). Clorazepate (32), ciprofloxacin (31), alprazolam (24), triazolam (24), prednisolone (54), ibuprofen (41), midazolam (49), thiopental (59), lorazepam (46), and verapamil (64) (Table 1). Only nitrazepam (50) and oxazepam (46) had a significantly different (increased) unbound fraction in obesity.

Obesity is associated in many patients with hyperlipidemia, which leads to elevated concentrations of lipoproteins in the blood (68). Some drugs are known to have a high degree of binding to lipoproteins, which could be associated with higher measures of total (sum of plasma proteinbound and unbound) drug concentrations. This in turn could influence the estimated Vd and/or CL of the drug. Most of the drugs that have been comparatively studied for the effects of obesity on pharmacokinetics in humans (Table 1, Figure 1) are not extremely lipophilic, or known to be highly bound to lipoproteins. For those in which the plasma unbound fraction was assessed, most were not likely to be significantly bound to lipoproteins. For drugs that are ligands for binding to lipoproteins, it would be the unbound concentration in plasma and the unbound drug CL that would be a more appropriate judge of the clinical relevance of the changes caused by obesity.

To adjust or not adjust clearance to body weight? Despite expectations, some authors have concluded that in the obese patient there are increases in drug CL $(75,76)$. In making these conclusions, the focus was on the body-weight unadjusted CL. Others, however, such as Harskamp-van Ginkel et al (77) in their examination of children, found that for most of the drugs examined, the CL was decreased. Of note, they focused on the CL normalized to the body weight of the children.

This issue is illustrated by the report of Mahmood (78), who collected CL values for a number of drugs from obese and non-obese subjects. In viewing the data as the CL unadjusted for body weight (volume per time), one would conclude that the CL of 10 of the 12 drugs was increased by obesity, in some cases strikingly so. However, by dividing each of the mean $\mathrm{CL}$ values by the respective mean total body weight, it becomes apparent that the body-weight adjusted CL is decreased for 8 of the 12 drugs.

While in many cases the weight-unadjusted CL is higher in obesity, does this truly indicate that the mechanisms involved in facilitating $\mathrm{CL}$ are accentuated in rate or magnitude? Total body CL is a function of the sum of individual organ CL, not simply lean body mass. In their commentary, Han et 

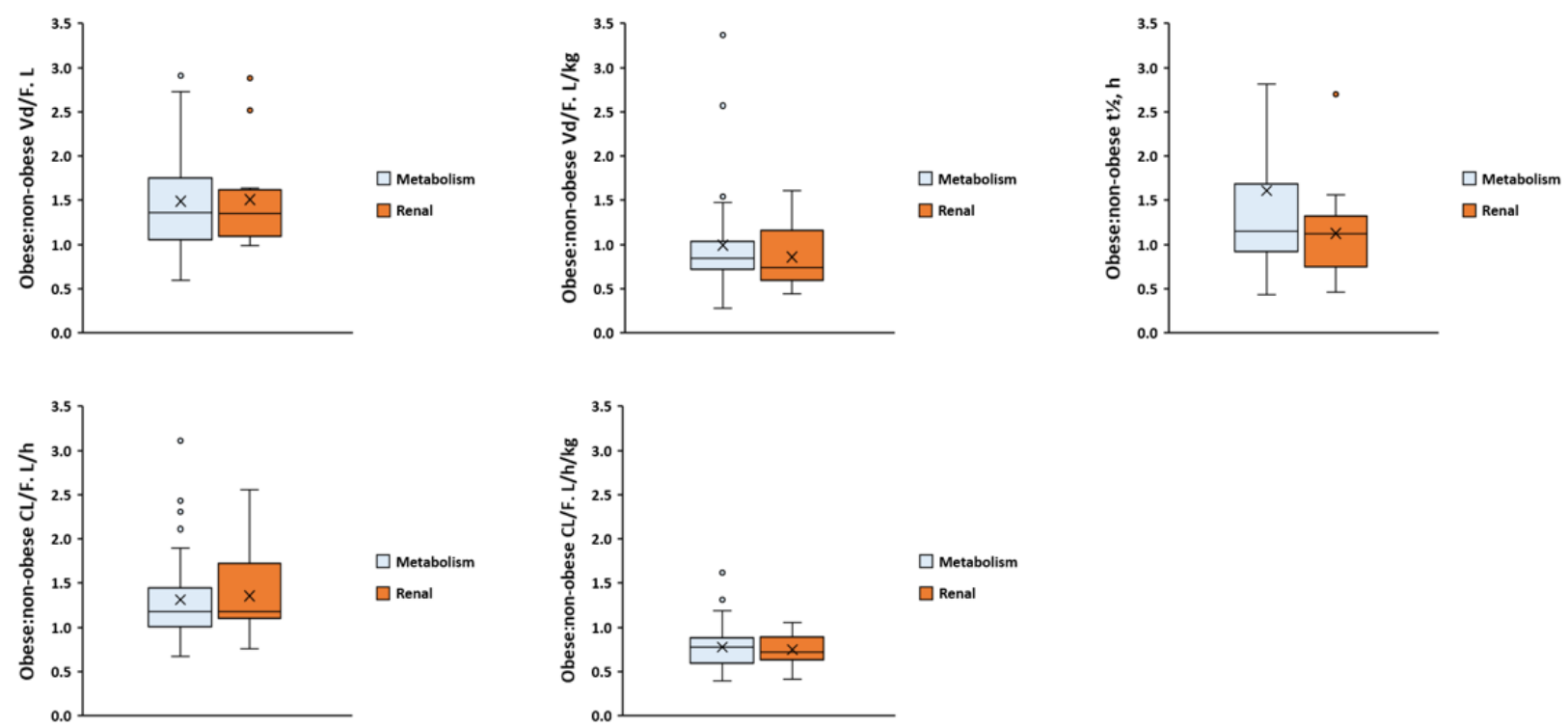

Figure 3. Comparisons between the obese to non-obese $\mathrm{CL} / \mathrm{F}, \mathrm{Vd} / \mathrm{F}$ and terminal phase half-life of drug that are primarily eliminated by metabolism or renal excretion of parent drug.
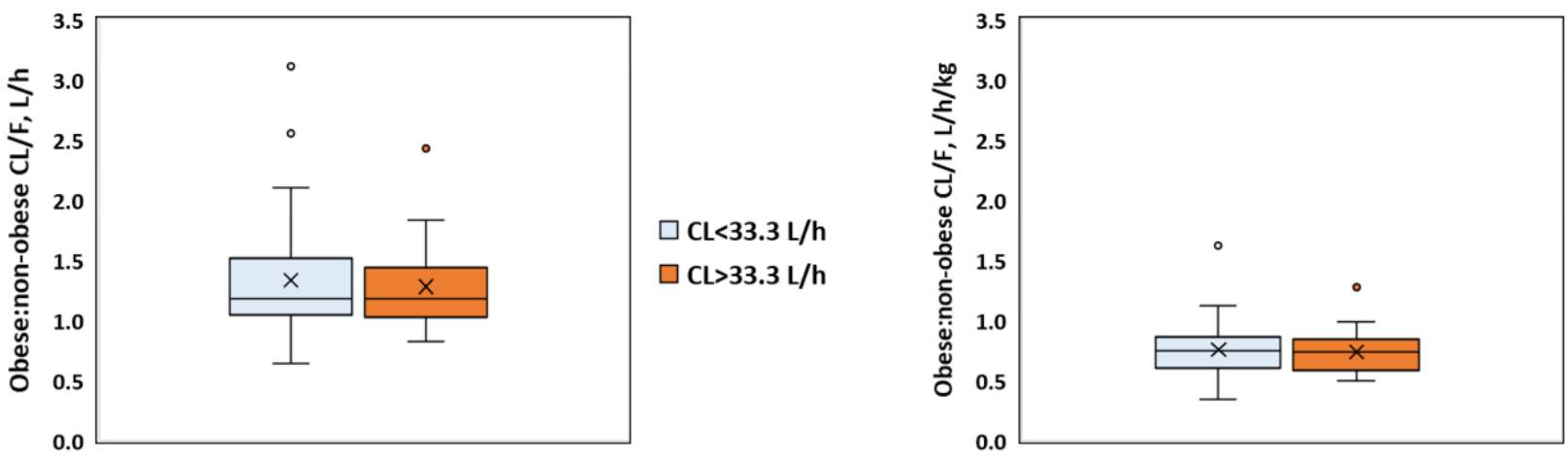

Figure 4. Obese to non-obese measures of CL/F for drugs with relatively higher and relatively lower values.

al (76) proposed that the metabolic processes are related to lean tissues, and extrapolated that lean body mass can be used to estimate the CL of a drug in obesity and be used for dosing the obese patient. This simplistic assumption neglects to consider the intrinsic levels of metabolizing efficiency. Further if blood flows to the tissues increase and/or eliminating organ tissue mass increases in obesity, this would invalidate the belief that lean tissue mass is maintained across the spectrum of BMI. The use of enoxaparin as an example (76) is problematic because it is not typically measured as unchanged parent drug, rather its effect being measured indirectly as anti-factor $\mathrm{Xa}$ in the plasma. This activity is not just dependent on parent drug, but also the activity of metabolites (79).
Similar to the findings of Mahmood (78) our search of comparative studies clearly shows that conclusions drawn of the effects of obesity on drug CL depends on whether the total weight-unadjusted or adjusted measures of CL are considered (Table 1). One would conclude based on body weightunadjusted CL values that there is either an increase or no change in CL. Figure 2 shows the disparity more clearly, where the mean ratios of obese to nonobese values from each study are summarized as box and whisker plots.

Clinically, drug CL is most of benefit tailoring the maintenance dose rate of a drug. In obesity considering that the relative CL of obese vs. nonobese are different for body-weight unadjusted or adjusted values, any changes in dosing are dependent on the point of view of the CL values used. In cases 
where the weight-unadjusted clearances show increases or no change, the natural conclusion would be that to attain a specified steady-state target concentration, one would use the same or a higher daily weight-unadjusted dose rate in the obese. However, if the weight-adjusted CL are lower, then one would conclude that the daily dose rate per $\mathrm{kg}$ would need to be reduced. Neither conclusion would be incorrect. However, use of the weight-normalized $\mathrm{CL}$ and normalizing the daily dose rate to body weight are both means of taking into account the individual demographic variable of body weight. Regardless, given that two conclusions can be reached depending on the metric used, a question is left unanswered as to whether the mechanisms involved in CL of a drug are decreased, unchanged, or increased in obesity.

Is human clearance of drugs increased or decreased? As is clear from Table 1 and Figure 1, the answer depends on which metric one chooses to view. A clear answer could be derived from examination of human expression of CYP isoforms, or other measures of functional activity at the level of the protein. However, practical limitations are inherent in obtaining microsomal proteins from human subjects. Examining metabolite to drug ratios may also be confounded by obesity-related downstream changes in drug and/or metabolite $\mathrm{CL}_{\text {renal }}$ or sequential metabolism (80) of the formed metabolites. While probes selective for specific isoenzymes can provide insight, one needs to consider that few probes are entirely isoformspecific. Data from animals becomes particularly insightful for understanding the mechanistic effects of obesity on metabolism or drug CL. Accordingly, in the next section we review the outcomes of preclinical studies involving obesity in laboratory rodents, and what is known of more detailed changes in drug elimination in humans. This data is then placed in context with the review of the CL in humans observed in pharmacokinetic studies.

Rodent models used to assess the effect of obesity. Most preclinical research into the effects of obesity have involved the use of rodents, notably mice and rats. Obesity in humans is linked to lifestyle and genetic factors. These can be mimicked in laboratory animal models to understand, amongst other things, the effects of obesity on pharmacokinetics, including drug metabolism.
Genetic rodent models of obesity. There are several genetically-linked experimental models of obesity available. Some of these have been nicely summarized in the review by Panchel and Brown (81). The models that are associated with obesity are for mice, the C57BL/6-ob/ob and (C57BL/KsJ-db/db mouse models, and for rats, the Zucker obese and Otsuka Long-Evans Tokushima fatty rat models. Another model not mentioned in the review is the JCR:LA-corpulent rat (82). Each of these models is associated with increases in body mass, and some can selectively serve as models for some of the associated cardiometabolic comorbidities of obesity such as hypertension, dyslipidemia, cardiovascular disease and glucose intolerance.

Dietary-induced obesity. In most cases of human obesity, diet is undoubtedly the major causative factor. While a clear definition of what constitutes "obesity" in rodents is not available, it is known that otherwise normal rodents can be made significantly overweight compared to animals given a standard diet by providing diets rich in sugars and/or fats for several weeks. Many studies have been published using mice and rats with high fat compositions with feedings typically ranging from 4 to at least 18 weeks before final assessments. In humans, obesity is caused by a combination of not just fats, but also diets rich in carbohydrates (notable fructose). The use of high carbohydrate-laden diets, such as high sucrose or fructose in combination with standard or high fat rat chow may also be used as a means of inducing overweight/obesity in rodents. Although not a typical dietary model, obesity and related metabolic changes have been uniquely induced by administration of monosodium glutamate subcutaneously during the first week after birth of mice (83).

The survey of studies undertaken indicates that the range of increase in weight is between 5 to over $60 \%$ (Supplementary Table 1) (83-116). In evaluating the results of studies involving rodents, it is important to consider the species, the diet or model used, the duration of feeding the high calorie diet, and the gender of the animals. Although there is no well-defined metric such as BMI for rats to help categorize the magnitude of overweight/obesity, these diets are very effective in increasing weight. For example, it has been noticed that female rats appear to be more resistant to weight gain than are males of the same species when fed the same high calorie containing meals $(96,103)$. It is possible that 
female rodents offer a unique insight into the effects of overweight rather than morbid obesity.

Another consideration in examining drug metabolism-related data from studies involving rodents obtained from examination of the serum biochemistry analysis. Pertinent factors include glucose, adipokines, liver function enzymes, and lipids. Each of these could potentially explain differences between studies. For example, an elevation in liver function enzymes may occur with some models using very high concentrations of dietary fat and would lend towards changes associated with nonalcoholic fatty liver disease (NAFLD), which can occur in obese people; this is associated with fatty infiltration and progression to fibrosis (117), each of which could hinder metabolic capacity by the liver. Other models using less fat might not cause elevations in liver function enzymes. In pharmacokinetic studies involving in vivo administration of drug, elevation in lipids and lipoproteins could lead to changes in the plasma protein binding of some lipophilic drugs (68), which could play a role in altering the CL of the drug by itself, even without changes in drug metabolizing enzymes.

\section{Studies into the effects of obesity on in vitro enzyme expression and drug metabolism}

Studies involving rodents. A number of investigations have been performed in rodents (mice, rats, and guinea pigs) to examine the effects of overweight/obesity on drug metabolizing enzymes. In Table 2, a summary of the data is shown from studies measuring protein concentration by immunoblot techniques or by activity using specific chemical probes $(83,85,87,89,96,97,99,100,104$, $105,108,116,118-128)$. Because mRNA is not the final determinant of the protein present, and because changes in mRNA do not always follow those of translation to protein or enzyme activity, those data are not included in this review.

Most studies employed high calorie dietary feedings (usually HFD) in otherwise normal rodents to achieve an overweight state, with fewer using genetically-based models of obesity (Table 2). Males were the most studied sex. Direct measurement of protein levels by Western blot was mostly used, with fewer using chemical probes to assess for the effects of obesity on metabolism. While liver was the main focus, in some studies enzyme expressions in other organs such as kidney or intestine were examined. There were approximately equal numbers of studies examining mice and rats. CYP was the most studied class of drug metabolizing enzyme.

There is some conflicting data regarding the effects of high calorie diets on total CYP. While Matsumoto et al. (129) found an increase in total CYP in rats given HFD for 40 weeks, Irizar et al. (123) found a $43 \%$ lower total CYP in obese vs. lean Zucker rats. In rats given HFD for 14 weeks, total CYP content was $44 \%$ that of Sprague-Dawley rats fed standard diet (98). On the other hand, in rats given high fructose diet alone or in combination with HFD, there were no changes in total CYP (98).

It was of interest that even though Matsumoto et al. (129) kept the rats for an extended 40-week period using a diet composed of one of the highest fat contents reported ( $80 \%$ by kcal), there were rats that failed to become obese according to their definition of $125 \%$ weight increase over controls. Those rats were removed from analysis. The authors kept their rats in groups of four to six in wire bottom cages for the entire period, and did not mention any monitoring of calorie intake in their rats, which might have explained why they did not increase in weight. One factor that might need to be considered in comparing variances in outcomes includes age of the rats at the conclusion of the study. Nevertheless, total CYP measures do not inform about the individual CYP isoforms involved in drug metabolism.

In many studies, there were changes in protein expression and/or functional activities of the important drug metabolizing enzymes. It is not possible to make an overarching conclusion about the effects of obesity on proteins affecting drug disposition, because the direction of any change depends on the protein involved. There are some differences in outcomes between studies, but there does appear to be a preponderance of consensus in looking at specific isoforms of enzymes.

This is highlighted in Table 3, wherein the effects of obesity on specific CYP isoforms (drawn from Table 2 data) are summarized. Of the CYP isoforms examined in the rodent studies, CYP3A was the most commonly assessed enzyme (Table 2), which is in accordance with the importance of CYP3A4 in human drug metabolism. Most of the available studies indicated that there was a decrease in the expression at the level of protein or in its activity. A similar observation is seen with CYP1A2 and CYP2C isoforms. The only isoform that appears to have a general increase in obesity in rodents is CYP2E1, where most investigators found either an increase or no change in expression. CYP2D has mostly been found to be unchanged. 
Table 2. Studies examining the effects of obesity on protein expression by Western blot (WB) or microsomal enzymatic activity by chemical probe (CP) of obese versus non-obese controls. $\downarrow$ decreased in obesity vs. control, $\uparrow$ increase in activity vs. control, $\leftrightarrow$ no change in obesity vs. control. Liver shown unless specified.

\begin{tabular}{|c|c|c|c|c|}
\hline \multirow{2}{*}{$\begin{array}{l}\text { Species } \\
\text { Rat, Sprague-Dawley }(96,97,99)\end{array}$} & \multirow{2}{*}{$\begin{array}{l}\text { Sex } \\
\text { Male }\end{array}$} & \multirow{2}{*}{$\begin{array}{l}\text { Model } \\
14 \text { weeks HFD }\end{array}$} & \multirow{2}{*}{$\begin{array}{l}\text { Method } \\
\text { WB }\end{array}$} & \multirow[b]{2}{*}{$\begin{array}{l}\text { Findings } \\
\text { CYP1A1 } \square \\
\text { CYP1A2 } \downarrow \\
\text { CYP2C11 } \\
\text { CYP2D1 } 1 \\
\text { CYP2E1 } \square \\
\text { CYP3A1 } \downarrow \\
\text { CYP3A2 } \downarrow \\
\text { Mate1 } \downarrow \\
\text { Mdr1 } \square \\
\text { Oct1 } \square\end{array}$} \\
\hline & & & & \\
\hline Rat, Sprague-Dawley $(99,118)$ & Male & 14 weeks HFCS & WB & $\begin{array}{l}\text { CYP1A1 } \square \\
\text { CYP2C11 } \\
\text { CYP2D1 } \uparrow \\
\text { CYP3A1 } \square \\
\text { CYP3A2 } \square \\
\text { Mate1 } \square \\
\text { Mdr1 } \square \\
\text { OCT1 } \square\end{array}$ \\
\hline Rat, Sprague-Dawley $(99,119)$ & Male & $\begin{array}{l}14 \text { weeks combined } \\
\text { HFD+HFCS }\end{array}$ & WB & $\begin{array}{l}\text { CYP1A1 } \square \\
\text { CYP2C11 } \\
\text { CYP2D1 } \uparrow \\
\text { CYP3A1 } \downarrow \\
\text { CYP3A2 } \downarrow \\
\text { Mate1 } \downarrow \\
\text { Mdr1 } \square \\
\text { OCT1 } \downarrow\end{array}$ \\
\hline Rat, Sprague-Dawley (120) & Male & 28 weeks HFD & WB and CP & $\begin{array}{l}\text { CYP 2C11 } \leftrightarrow \\
\text { CYP3A } \leftrightarrow\end{array}$ \\
\hline Rat, Sprague-Dawley (96) & Female & 14 weeks HFD & WB & $\begin{array}{l}\text { CYP1A2 } \downarrow \\
\text { CYP2C12 } \downarrow \\
\text { CYP2D1 } \leftrightarrow \\
\text { CYP2E1 } \square \\
\text { CYP3A1 } \downarrow\end{array}$ \\
\hline Rat, Sprague-Dawley (104) & Female & 13 weeks HFD & WB & $\mathrm{CYP} 3 \mathrm{~A} 2 \uparrow$ \\
\hline Rat, Sprague-Dawley (99) & Male & 14 weeks HFD & WB & $\begin{array}{l}\text { Kidney } \\
\text { Mate } \square \\
\text { Mdr1 } \square \\
\text { OCT1 } \square \\
\text { OCT2 } \downarrow\end{array}$ \\
\hline Rat, Sprague-Dawley (99) & Male & 14 weeks HFCS & WB & $\begin{array}{l}\text { Kidney } \\
\text { Mate } \square \\
\text { Mdr1 } \square \\
\text { OCT1 } \square \\
\text { OCT2 } \square\end{array}$ \\
\hline Rat, Sprague-Dawley (99) & Male & $\begin{array}{l}14 \text { weeks } \\
\text { HFD+HFCS }\end{array}$ & WB & $\begin{array}{l}\text { Kidney } \\
\text { Mate } \square \\
\text { Mdr1 } \square \\
\text { OCT1 } \downarrow \\
\text { OCT2 } \downarrow\end{array}$ \\
\hline Rat, Sprague-Dawley (100) & Male & 52 weeks HFD & $\mathrm{CP}$ & $\mathrm{CYP} 2 \mathrm{E} 1 \uparrow$ \\
\hline Rat, Sprague-Dawley (105) & Male & 52 weeks HFD & $\mathrm{WB}, \mathrm{CP}$ & $\begin{array}{l}\text { CYP1A2 } \downarrow \\
\text { CYP2B1 } \downarrow \\
\text { CYP2C11 } \\
\text { CYP2D } \square \\
\text { CYP2E1 } \square \\
\text { CYP3A1 } \downarrow \text { WB/ } \square \square \text { CP } \\
\text { UGT1A1 } \\
\text { UGT1A } 3 \\
\text { UGT1A } 8 \downarrow \\
\text { UGT1A9 } \\
\text { UGT2B7 }\end{array}$ \\
\hline Rat, Wistar (116) & Male & 8 weeks HFD & WB & $\begin{array}{l}\text { CYP3A } \downarrow \\
\text { P-gp } \downarrow\end{array}$ \\
\hline Rat, Wistar (116) & Male & 8 weeks HFD & WB & $\begin{array}{l}\text { Intestine } \\
\text { CYP3A } \\
\text { P-gp } \downarrow \\
\text { Table 2. continues... }\end{array}$ \\
\hline
\end{tabular}


Rat, Wistar (121)

Rat, Zucker obese (122)

Rat, Zucker lean and obese (123)

Rat, Zucker obese (108)

Rat, Zucker lean (108)

Mouse, C57BL/6J (96)

Mouse, C57BL/6J (96)

Mouse, C57BL/6J (124)

Mouse, C57BL/6 (125)

Mouse, C57BL/6J (85)

Mouse, Tg-CYP2D6 (87)

Mouse, NMRI (83)

Mouse, CD1 (89)
Male

Male

Male

Lean vs obese rats

16-18 weeks

WB

CP

Male

20 weeks

12 weeks HFD

Male

Male

Male

Male

Male

Male
10 weeks HFD

10 weeks HFD

9 weeks HFD

14 weeks $60 \%$ HFD
14 wk HFD

18 weeks HFD

Monosodium glutamate
WB

WB

CP

CP

WB

WB

WB

WB

WB

7-month-old

8-month-old

12 weeks old

Control vs. combined HFD

and high sucrose/fructose diets; age and feeding duration undisclosed
CYP1A1

CYP1A2

CYP2B1

CYP3A

UGT $\uparrow$

Cyp3a2 $\downarrow$

P-gp $\square$

CYP total $\downarrow$

CYP1A1

CYP1A2

CYP2B

CYP2E

CYP3A

CYP4A

Liver

CYP2E1 $\uparrow$

UGT $\square$

Kidney

CYP2E1

$\mathrm{UGT} \uparrow$

Adipose

CYP2E1 $\uparrow$

Liver

CYP2E1 $\uparrow$

UGT $\square$

Kidney

CYP2E1

$\mathrm{UGT} \uparrow$

Adipose

CYP2E1 $\uparrow$

Cyp1a2 $\downarrow$

Cyp2e1 $\uparrow$

Cyp3a41 $\downarrow$

Cyp1a2 $\downarrow$

Cyp2e1 $\uparrow$

Cyp3a41 $\downarrow$

Cyp2b $\downarrow$

Cyp2c $\downarrow$

Cyp2d $\square \square \downarrow$

Cyp2e1 $\uparrow$

Cyp $2 \mathrm{j} 5 \downarrow$

Cyp3a11 $\downarrow$

Cyp2c $\downarrow$

Cyp2d $\uparrow$

Cyp3a $\downarrow$

Oct $1 \uparrow$

Cyp2d6 $\leftrightarrow$

Cyp1A1/2

Cyp2a5

Cyp2c $\square$

Cyp2d $\square$

Cyp2e1 $\uparrow$

Cyp3a $\square$

Cyp2b10 $\downarrow$

Cyp3a11

Ugt1a1 $\downarrow$

Sulf1a1 $\downarrow$

PXR $\downarrow$

CAR $\downarrow$

RXR $\square \downarrow$

Intestine

Cyp3a $\downarrow$

Cyp3a $\downarrow$

Cyp1a1 $\square$

Cyp2b1 $\uparrow$

Cyp 2e1 $\downarrow$

Cyp 4a $\square$

CYP3A $\downarrow$ 
Table 3. Summary of change in hepatic CYP in rodent studies shown in Table 2 (plus recent ref 158).

\begin{tabular}{lccc}
\hline CYP & Decreased & Unchanged & Increased \\
\hline $1 \mathrm{~A} 1$ & 0 & 7 & 0 \\
$1 \mathrm{~A} 2$ & 6 & 4 & 0 \\
2B & 3 & 2 & 1 \\
2C & 6 & 2 & 0 \\
2D & 2 & 6 & 3 \\
2E & 2 & 3 & 7 \\
2J & 1 & 0 & 0 \\
$3 \mathrm{~A}$ & 16 & 6 & 1 \\
$4 \mathrm{~A}$ & 0 & 2 & 0 \\
\hline
\end{tabular}

Most studies did not employ more than a single high calorie diet arm, or have used both male and female animals in the same study. Our group examined the effects of 3 test diets, one high in fat, high in fructose, or a combination of both fat and fructose. High fructose by itself caused less weight gain that those diets including fats. Except for triglycerides which were higher in the HFCS alone group, other biochemical data in serum were similar in the test diet groups. The animals given diets rich in fats had more changes in CYP than did those animals receiving HFCS without excess fats. It was of interest that the inclusion of HFCS in the diets led to an increase in CYP2D1, something not associated with an excess of fats in the diet. In another study where both sexes were examined, female rats given a HFD for 14 weeks experiences similar changes in several CYP as males compared to control rats given a standard diet (decreases in CYP1A2, 2C and 3A1) although in females CYP2D1 did not change whereas it decreased in males. Chlorzoxazone is a CYP2E substrate, and the results of increased $\mathrm{CL}$ is consistent with the general observation of an increase of CYP2E1 in obese rats (Tables 3 and 4).

In a very recent report, birth weight did not appear to influence the effects of a high fructose/HFD (3.5 months) on CYP activities in guinea pigs (158). The obese male and female rats both had decreases in CYP3A, no changes in 2D6, but only obese males had decreases in 1A2 activities.

Phase 2 metabolism was much less studied than CYP, and in some cases specific isoforms were not examined. One study reported the decreased expression of several UGT isoforms in rats fed HFD (105). One study in mice examined sulfatase activity and Ugt1a1 activity and found obesity-related decreases in both (89). Some of the data from humans for highly glucuronidated and/or sulfated drugs such as propofol (56), oxazepam (46) and levonorgesterol
(43) suggested a possible increase in UGT activity, given that for both the body-weight and unadjusted CL the mean ratios of obese to non-obese subjects were more than 1 (Table 1).

Besides binding of drug to lipoproteins, the obesity-related comorbidity of hyperlipidemia has also been shown to cause decreases in CYP expressions and activities in rodents $(68,98,130$, 131).

Data from humans. While there are many articles devoted to the expressions of proteins involved in determining transport and metabolism in preclinical species, there is little direct evidence from obese human tissues. There have been some investigations involving liver tissues or cells histologically established as being from patients with NAFLD, which is commonly associated with obesity (132134). Fisher et al studied the expressions of a number of CYP in humans with varying degrees of NAFLD at the mRNA and the protein levels (132). In their protein analysis (Western blots), they found trends towards decreases in CYP1A2, CYP2C8, CYP2C19, CYP2D6, CYP2E1 and CYP3A4. They found no apparent changes in $\mathrm{CYP} 2 \mathrm{~B} 6$ or $2 \mathrm{C} 9$, and a trend towards an increase in $2 \mathrm{~A} 6$ with the presence of the liver disease. The use of chemical probes gave mostly consistent results compared to observed in protein content with the exception of CYP2C9 (trend to increase) and CYP2E1 (no trend to change). While the changes were linked to severity of liver disease, the data cannot be definitively linked to obesity because the authors did or could not provide information about the patient's BMI or body weight.

In 2020, Zarezadeh et al reviewed the available studies examining the effects of human obesity on CYP drug metabolizing activities (135). Most of the studies indicated a decrease in CYP1A2 and CYP3A4/5. There were variable study results for CYP2C and CYP2D6, but an increase in CYP2E1 activities. The authors did not state whether they used body weight adjusted or non-adjusted CL values to evaluate their data, although several of the summary data are supported by liver enzyme activities in NAFLD samples (132).

\section{Pharmacokinetic studies in obese rodents}

There have been only a limited number of studies examining the pharmacokinetics of drugs in animal models of obesity, aside from those involving "specific" probes for CYP activity. Nevertheless, the findings in those available usually match what was found in assessments changes in the enzymes responsible for their metabolism. These studies, 
unlike humans, tend to dose the animals on a mass per total body weight basis. As is seen in Table 4, obese rats tend to have higher levels of systemic exposure based on AUC compared to their control non-obese animals $(97,101,108,115,116)$. Some of the specific findings are discussed below.

Table 4. Systemic exposure of drugs in obese relative to control non-obese rats given various drugs. All involve administration of doses given the same mass per body weight basis.

\begin{tabular}{|c|c|c|}
\hline Drug & Model & $\begin{array}{l}\text { Obese:non- } \\
\text { obese ratio of } \\
\text { plasma AUC }\end{array}$ \\
\hline $\begin{array}{l}\text { Acetaminophen ip } \\
\text { (115) }\end{array}$ & $\begin{array}{c}\text { Male Sprague-Dawley } \\
\text { HFD }\end{array}$ & 1.48 \\
\hline Amiodarone (97) & $\begin{array}{c}\text { Male Sprague-Dawley } \\
\text { HFCS+HFD }\end{array}$ & 1.51 \\
\hline Atanazavir iv (101) & $\begin{array}{c}\text { Male Wistar-Hannover } \\
\text { HFD }\end{array}$ & 1.94 \\
\hline $\begin{array}{l}\text { Atanazavir po } \\
\text { (101) }\end{array}$ & $\begin{array}{c}\text { Male Wistar-Hannover } \\
\text { HFD }\end{array}$ & 2.45 \\
\hline $\begin{array}{l}\text { Chlorzoxazone iv } \\
(108)\end{array}$ & Male Zucker obese rat & 0.76 \\
\hline $\begin{array}{l}\text { Chlorzoxazone iv } \\
(108)\end{array}$ & $\begin{array}{c}\text { Male Zucker lean rat } \\
\text { HFD }\end{array}$ & 0.89 \\
\hline Nelfinavir iv (116) & Male Wistar HFD & 1.45 \\
\hline Nelfinavir id (116) & Male Wistar HFD & 1.70 \\
\hline $\begin{array}{l}\text { Theophylline iv } \\
\text { (103) }\end{array}$ & $\begin{array}{c}\text { Male Sprague-Dawley } \\
\text { HFD }\end{array}$ & 1.83 \\
\hline Verapamil iv (136) & $\begin{array}{c}\text { Female lean and obese } \\
\text { Zucker rats }\end{array}$ & 2.10 \\
\hline Verofylline (137) & $\begin{array}{c}\text { Male Sprague-Dawley } \\
\text { HFD }\end{array}$ & 0.66 \\
\hline
\end{tabular}

Khemawool et al examined the pharmacokinetics of intravenous chlorzoxazone (a CYP2E1 substrate) in lean Zucker rats after standard or high fat diet, and genetically obese Zucker rats (108). They also measured its 6-hydroxy metabolite under these conditions after chlorzoxazone. The CL in $\mathrm{L} / \mathrm{h} / \mathrm{kg}$ of parent drug was significantly higher in the fa/fa rats and in the rats given HFD. They also observed an increased AUC of the 6-hydroxy metabolite in the obese rats. The $\mathrm{Vd}_{\mathrm{ss}}$ was higher in the obese and HFD groups of rats (reported as L/h, but likely $\mathrm{L} / \mathrm{kg}$ ).

Decreases have been seen in the CL/F of nelfinavir in rats fed HFD after both intravenous and oral administration (116). The authors found that the $f_{u}$ in plasma was decreased in the HFD rats leading to a decrease in the AUC of unbound drug under those conditions for both routes of administration. Even though the rats were only $6 \%$ different in weight, the HFD rats displayed significant increases in LDL, liver function enzymes and glucose. There was no change in CYP activity noted in this study, perhaps because the weight increase was so modest, and the PK changes can be largely attributed to differences in plasma protein binding (likely increased lipoprotein binding) brought on by the diet. The same research group also found a similar effect of obesity on the CL of the antiviral drug atanazavir with significantly higher AUC being attained after HFD with matching intravenous and oral doses per $\mathrm{kg}$ of drug (101).

In obese Zucker female rats there was a significantly higher AUC compared to lean Zucker female rats after a single iv dose, which was accompanied by a decrease in the total body weight but not weight-unadjusted CL. The $\mathrm{Vd}_{\text {area }}$ adjusted for total weight did not differ between the two groups, nor was there a difference in the unbound fraction in plasma (136).

The Phase 2 metabolism of acetaminophen conjugation has been reported in obese rats after 287 $\mathrm{mg} / \mathrm{kg}$ intraperitoneal (ip) doses (115). There was a significant decrease in the CL of acetaminophen in HFD rats. The formation CL of acetaminophen by sulfation but not glucuronidation were found to be significantly decreased in the obese rats. Another group found that with higher doses of at least 710 $\mathrm{mg} / \mathrm{kg}$ acetaminophen renal excretion of acetaminophen and conjugated metabolites to be decreased in obese rats, with greater liver damage and lethality than standard control diets (106).

The CL of theophylline, a CYP1A2 substrate, was significantly decreased in obese male rats given $20 \mathrm{mg} / \mathrm{kg}$ iv theophylline given as aminophylline (103). They noted that the HFD was unable to induce obesity in female rats, so they did not compare the pharmacokinetics in female mice given HFD or standard diet.

Rats fed a combination of high fat and fructose experienced a significantly higher oral amiodarone AUC when compared to those fed a standard diet for 14 weeks (97). The tissue concentrations were also studied as well as concentrations of the main dealkylated metabolite (formed from amiodarone by multiple CYP isoforms (138) being measured. In plasma the metabolite to drug ratio of AUC was decreased in obesity. Higher exposure was seen in the heart, but this was in accordance with the higher concentrations in the plasma. The findings in those rats were in line with the kinetics of desethylamiodarone formation from in liver microsomes, where the intrinsic formation $\mathrm{CL}$ was lower in HFD, HFCS and combined HF+HFCS dietary treated rats. Similarly, in rats fed HFD, the intrinsic CL of lidocaine to its main dealkylated metabolite was decreased (96). In surgical patients given lidocaine as rectus sheath injection (139), the 
correlation of weight-unadjusted lidocaine plasma $\mathrm{CL}$ was weak and not significant $(\mathrm{r}=-0.22, \mathrm{p}>0.05)$. However, when viewed as weight-normalized CL, there was a significant negative correlation of plasma CL with BMI $(r=-0.85, p<0.05)$. Hence the weight normalized $\mathrm{CL}$ was in line with the observations from the rat liver microsomal study. The metabolism of dronedarone to its main dealkylated metabolite was complex in liver microsomes, but with high calorie diets generally causing decreases in the rate of metabolite formation (98).

Jang et al. (85) found that HFD in mice led to increase in liver Oct1 expression and increases in metformin exposure in liver and plasma, and the liver to plasma concentration ratio after ip dosing. The increase in the liver to plasma ratio was matched with an increased expression of Oct1 in the liver tissue. The increase in Oct1 in the mice may have been due to the increases in leptin and insulin, given that in HepG2 cells (human) their presence was also associated with increases in OCT1 expression at the transcription level. It did not appear to be related to $\mathrm{TNF} \alpha$, since it had no effect on mRNA expression in HepG2 cells. Intraperitoneal administration of leptin (source species not disclosed, but presumably human) to obese mice caused decreases in Cyp1a1 and Cyp2b, increases in Cyp2e1 and no change in CYP4a activities (127). Insulin infusions were observed in dairy cows to lower mRNA expressions of CYP2C and 3A in liver isolated by biopsy, in an infusion rate-dependent fashion (140).

In a study involving male lean and genetically obese Zucker rats given iv tacrolimus, it was found that the body-weight unadjusted CL was not significantly different between obese and lean rats (122). While the rats were dosed on a $\mathrm{mg} / \mathrm{kg}$ basis and the authors expressed the $\mathrm{Vd}_{\mathrm{ss}}$ as weight unadjusted and adjusted values, they only showed the $\mathrm{CL}$ as unadjusted values. If adjusted for the total weight given, the mean CL appears to be lower in the obese than the lean rats $(12.4$ vs. $19.1 \mathrm{~mL} / \mathrm{min} / \mathrm{kg}$, respectively) matching the observed lower mean $\mathrm{Vd}_{\mathrm{ss}}$ (4.26 vs. $6.29 \mathrm{~L} / \mathrm{kg}$, respectively). Such a difference in weight-normalized CL was consistent with the authors finding of significant decreases in hepatic CYP3A2 in the obese rats. The authors also studied intestinal CYP3A2 and P-gp expressions at the protein level in the rats and found no differences in lean and obese in $3 \mathrm{~A} 2$, but significant decreases in $\mathrm{P}$ gp expression in the upper regions of the intestinal tract. After oral doses, the authors reported a significantly higher CL/F for weight unadjusted values (factor of 2.97 lower in obesity). If the body weight adjusted CL are calculated the fold-difference between lean and obese rats became even larger (factor of 4.82 lower in obesity). The combined data showed that both lower hepatic CYP3A2 and intestinal P-gp expressions are fully compatible with the higher lean to obese measurements of tacrolimus $\mathrm{CL} / \mathrm{F}$, when expressed on a weight normalized basis, for both iv and po routes.

Not all drugs in rodents had increased AUC after HFD. In male Sprague-Dawley rats fed HFD for 14 months, prednisolone was given at variable iv doses and the pharmacokinetics studied (141). The body-weight-normalized CL did not differ between the normal and obese rats, suggesting the same AUC in rats given the same dose on a weight-normalized basis. The same gtoup also observed that verofylline had a $52 \%$ increase in the weight-normalized CL after 32 weeks of an $80 \%$ kcal HFD for 32 weeks (137). Unfortunately, we could not find any information on the fate of the drugs in the literature that might help explain the result.

\section{Does obesity affect blood flows to liver and kidney, and/or organ weights?}

Drug CL is dependent not just on enzyme and excretory transport protein function, but also on the rate at which it is delivered to the organ by the blood. To permit adequate oxygenation and proper function of the larger mass of tissues in obesity, blood volume and cardiac output both increase in obese people in a linear fashion (142). Some key review articles (143, 144) also concluded that renal blood flow and cardiac output tend to increase in obesity across species, including humans.

However, a different conclusion is reached if those flow rates are normalized to total body weight. For example, the blood volume and cardiac output are both reduced by $45 \%$ and $40 \%$, respectively, in obesity (142). Likewise in the work of Carrol et al. (145) the data showed increases in cardiac output and in several organ blood flows in obese compared to non-obese rabbits. However, if the flow per $g$ of tissue or flow divided by the mean body weights are examined, there is no apparent difference between obese and non-obese animals in liver or kidney blood flow rates. They also observed increases in organ sizes, including kidney and liver. In a veterinary clinical study in dogs, obesity was associated with abnormalities in portal vein hemodynamics, including a decrease in portal blood flow volume (146).

Increases in liver size have also been noted in Sprague-Dawley and Wistar rats fed HFD of varying 
fat content for 8 to 40 weeks $(96,129,141,147-149)$. The increases in liver weight in HFD rats vs. standard diet rats ranged between 17 and $37 \%$ in each of these studies. However, when the increases in liver weights relative to total body weight was calculated, the values became not significantly difference in all cases. The mean $\pm \mathrm{SD}$ of the average increase in body weights, liver weights, and liver weight per body weights were $28.3 \pm 14 \%, 26.5 \pm 7.9 \%$ and $0.99 \pm 0.11 \%$, respectively in these studies $(96,129$, 141, 147-149). Linear increases in liver, pancreas and kidney in obesity were also more recently reported in humans (applying weighted linear regression) (150). In the study of Hall et al in dogs (151), although increases in cardiac output, GFR and renal blood flow were apparent in obese dogs, when divided by body weight at the end of the study, the differences in flows dissipated for cardiac output and renal blood flow, and GFR seemed to be lower in obese dogs. Hence it would appear that obesity changes eliminating organ mass but retains the same blood flow per organ weight. However, another consideration in viewing blood flows is the microcirculation within the organs. For liver, a review of the topic has found that fatty liver is associated with alterations in the sinusoidal blood flow, which could potentially mean decreases in the blood flow to the hepatocytes, with consequences in hepatic CL of drugs with higher extraction ratios. Perhaps this explains the observation in Figure 4 where for drugs with higher CL, there was a trend to lower weight-normalized obese to non-obese CL.

In viewing metabolism, it may be tempting to make conclusions that the changes in drug metabolism expected can be estimated by calculating the product of changes in enzyme expression by the mass of the liver. This likely oversimplifies expectations, and may lead to a false conclusion, because the constitution of the liver, including factors such as the proportion that is fat, number and density of hepatocytes and functional activity at the organ level, are all potentially changed in obesity (152).

Drugs with high plasma CL in lean rats were reported to have lower body weight-normalized CL in obese rats than those with lower values of CL (147). While this may suggest a reduction in hepatic blood flow, it is noted that the values were based on plasma and not blood and were not corrected for the blood to plasma ratios (153). Underlying this caution is that some of the plasma CL values exceeded those of hepatic blood flow in the rat $(55 \mathrm{~mL} / \mathrm{min} / \mathrm{kg})(154)$ which suggests extrahepatic CL occurring for those drugs in the rat (assuming a blood to plasma ratio of 1). It would appear that fatty liver disease, which is a comorbidity in some obese people, is associated with decreases in hepatic blood flow and liver microcirculatory flow $(146,155)$.

\section{How reversible are changes in protein expression caused by obesity?}

In cases of effective weight loss due to management of lifestyle or other therapeutic intervention, there is information that a reversal of obesity-related alterations in drug disposition can be achieved. It has been shown that in HFD rats, after achieving a state of obesity, normalization of the diet can lead to preobesity changes even in the absence of significant weight loss. This occurs at both the protein expression and metabolizing enzyme activity levels (96). Data not shown in that paper was information that the liver weights became the same in the control and HFD rats after the 4 weeks of feeding the rats in the HFD group a standard diet. Another example has been observed for metformin where after bariatric surgery, pharmacokinetic changes in $\mathrm{CL} / \mathrm{F}$ and bioavailability became closer to those of the mostly non-obese population after the surgery (156).

\section{Concordance between human and animal data}

There are few drugs where the pharmacokinetics in obesity have been examined in both rats and humans. Examples include acetaminophen and verapamil, and in both cases, there were increases in the AUC after giving the same dose per body weight to control and those given HFD, and these were matched by lower weight normalized CL values in humans (Table 1 and Table 4). The combined data from human and animal studies suggests that at the level of protein expression and functional activity, there are general decreases in expression and functional activities of intrinsic drug CL mechanisms.

Nevertheless, some authors have suggested that in humans, total-drug body CL usually increases in obesity. The apparent disparity in these observations can be attributed to the selection of the values used to render those conclusions in clinical pharmacokinetic studies. It is apparent that using body-weight unadjusted values of human comparative studies, CL generally appears to increase. In some cases, authors have recommended that dosing be based on CL adjusted to lean or ideal body weight. This typically would lead to a recommendation of the need for a larger dose in the 
obese patient. However, if the CL normalized to the total body weight is examined, the CL tends to decrease in obesity (Table 1); this would necessitate a lower dose in mass per $\mathrm{kg}$ for the obese patient. In both cases, the outcome in dosing is the same. An implicit assumption of using $\mathrm{CL}$ unadjusted to weight or adjusting to lean body weight is that liver and kidney weights are unchanged in obesity. This assumption is violated, however, because changes occur in liver and kidney weights and blood flows in obesity. Conclusions about the effects of obesity on drug CL based on the use of CL values unadjusted to total body weight tend to obscure mechanistic changes in drug CL, including the obesity-related decreases in the expressions and functions of several important drug metabolizing enzymes including CYP3A, CYP1A2 and CYP2C.

\section{CONCLUSION}

The CL and rates of metabolism of drugs appears to be generally decreased in the presence of experimental obesity, and from available enzyme expression levels in humans. These findings match calculations of CL normalized to total body weight, but not unadjusted CL or CL adjusted for measures of lean body mass. While body weight unadjusted CL may still be used for dosing of the obese patient, it should be recognized that it may be misleading to use it to render conclusions about hoe obesity affects intrinsic drug eliminating processes. Studies involving assessment of $\mathrm{CL}$ in the obese patient should consider not just the unadjusted CL, but also take into account the weight-adjusted CL to gain full insight into the effect of obesity on drug elimination.

Most of the studies examining the effects of obesity on drug pharmacokinetics were not designed to examine whether drug effectiveness or safety is altered by the condition. Some authors have looked at the pharmacokinetic-dynamic relationship. For example, obese patients seem to require higher steady-state atracurium concentrations in blood than the non-obese to get the same level of effect (25). Verapamil also appears to be associated with a reduction in the affinity of the drug for its receptors in the obese, as evidenced by a higher concentration needed for attainment of 50\% of maximal effect (PR interval lengthening). This was despite a lack of change in the unbound fraction in the plasma (64). Similarly, the relative effectiveness in calcium channel blockers in reducing systolic blood pressure appears to be diminished in obese pediatric patients (11).
Further study is needed to identify what factors associated with obesity give rise to the reduced expression and CL of drugs. These could assist in completing our understanding of how the condition can alter drug clearance and metabolism. An increased understanding of the relationship between the pharmacokinetics, concentrations achieved in the blood fluids and the effect of the drug in obesity is also needed to improve tailoring of drug dosing requirements, safety, and efficacy.

\section{CONFLICT OF INTEREST. None.}

\section{REFERENCES}

1. Brocks DR, Ben-Eltriki M, Gabr RQ, Padwal RS. The effects of gastric bypass surgery on drug absorption and pharmacokinetics. Expert Opin Drug Metab Toxicol. 2012 Dec;8(12):1505-19. DOI: 10.1517/17425255.2012.722757

2. Nadolsky KZ, Hurley DL, Garvey WT. Covid19 \& Obesity: Beyond Bmi. Endocr Pract. 2020 Aug;26(8):923-5. DOI: 10.4158/EP-2020-0302

3. Stefan N, Birkenfeld AL, Schulze MB. Global pandemics interconnected - obesity, impaired metabolic health and COVID-19. Nat Rev Endocrinol. 2021 Jan 21. DOI: 10.1038/s41574020-00462-1

4. Zhao X, Gang X, He G, Li Z, Lv Y, Han Q, et al. Obesity Increases the Severity and Mortality of Influenza and COVID-19: A Systematic Review and Meta-Analysis. Front Endocrinol (Lausanne). 2020;11:595109. DOI: 10.3389/fendo.2020.595109

5. Chiappetta S, Sharma AM, Bottino V, Stier C. COVID-19 and the role of chronic inflammation in patients with obesity. Int J Obes (Lond). 2020 Aug;44(8):1790-2. DOI: 10.1038/s41366-0200597-4

6. Ghanemi A, St-Amand J. Redefining obesity toward classifying as a disease. Eur J Intern Med. $2018 \quad$ Sep;55:20-2. DOI: 10.1016/j.ejim.2018.05.025

7. Sharma AM, Campbell-Scherer DL. Redefining obesity: Beyond the numbers. Obesity (Silver Spring). 2017 Apr;25(4):660-1. DOI: 10.1002/oby.21801

8. Team C. The impact of obesity on drug prescribing in primary care. Br J Gen Pract. 2005 Oct;55(519):743-9

9. Martin AR, Klemensberg J, Klein LV, Urbach D, Bell CM. Comparison of public and private 
bariatric surgery services in Canada. Can J Surg. 2011 Jun;54(3):154-69. DOI: 10.1503/cjs.048909 [pii] 10.1503/cjs.048909

10. Maury E, Ehala-Aleksejev K, Guiot Y, Detry R, Vandenhooft A, Brichard SM. Adipokines oversecreted by omental adipose tissue in human obesity. Am J Physiol Endocrinol Metab. 2007 Sep;293(3):E656-65. DOI: 00127.2007 [pii] 10.1152/ajpendo.00127.2007

11. Hanafy S, Pinsk M, Jamali F. Effect of obesity on response to cardiovascular drugs in pediatric patients with renal disease. Pediatr Nephrol. 2009 Apr;24(4):815-21. DOI: 10.1007/s00467008-1064-y

12. Lago F, Gomez R, Conde J, Scotece M, GomezReino JJ, Gualillo O. Cardiometabolic comorbidities and rheumatic diseases: focus on the role of fat mass and adipokines. Arthritis Care Res (Hoboken). 2011 Aug;63(8):1083-90. DOI: 10.1002/acr.20488

13. Kotsis V, Stabouli S, Papakatsika S, Rizos Z, Parati G. Mechanisms of obesity-induced hypertension. Hypertens Res. 2010 May;33(5):386-93. DOI: hr20109 [pii] 10.1038/hr.2010.9

14. Wong SL, DePaoli AM, Lee JH, Mantzoros CS. Leptin hormonal kinetics in the fed state: effects of adiposity, age, and gender on endogenous leptin production and clearance rates. J Clin Endocrinol Metab. 2004 Jun;89(6):2672-7. DOI: 10.1210/jc.2003-031931 89/6/2672 [pii]

15. Lumeng $\mathrm{CN}$, Saltiel AR. Inflammatory links between obesity and metabolic disease. J Clin Invest. 2011 Jun 1;121(6):2111-7. DOI: 10.1172/JCI57132 57132 [pii]

16. Morris DL, Singer K, Lumeng CN. Adipose tissue macrophages: phenotypic plasticity and diversity in lean and obese states. Curr Opin Clin Nutr Metab Care. 2011 Jul;14(4):341-6. DOI: 10.1097/MCO.0b013e328347970b

17. Maury E, Ehala-Aleksejev K, Guiot Y, Detry R, Vandenhooft A, Brichard SM. Adipokines oversecreted by omental adipose tissue in human obesity. Am J Physiol Endocrinol Metab. 2007 Sep;293(3):E656-65. DOI: 10.1152/ajpendo.00127.2007

18. Neels JG, Olefsky JM. Inflamed fat: what starts the fire? J Clin Invest. 2006 Jan;116(1):33-5. DOI: $10.1172 / \mathrm{JCI} 27280$

19. Weisberg SP, McCann D, Desai M, Rosenbaum M, Leibel RL, Ferrante AW, Jr. Obesity is associated with macrophage accumulation in adipose tissue. J Clin Invest. 2003
Dec;112(12):1796-808.

DOI: 10.1172/JCI19246112/12/1796 [pii]

20. Blumenfield DE. Means and Variances. Operations Research Calculations Handbook. Boca Raton: CRC Press; 2001.

21. Abernethy DR, Divoll M, Greenblatt DJ, Ameer B. Obesity, sex, and acetaminophen disposition. Clin Pharmacol Ther. 1982 Jun;31(6):783-90. DOI: $10.1038 /$ clpt.1982.111

22. Greenblatt DJ, Abernethy DR, Boxenbaum HG, Matlis R, Ochs HR, Harmatz JS, et al. Influence of age, gender, and obesity on salicylate kinetics following single doses of aspirin. Arthritis Rheum. 1986 Aug;29(8):971-80. DOI: 10.1002/art.1780290805

23. Turner RB, Cumpston A, Sweet M, Briggs F, Slain D, Wen S, et al. Prospective, Controlled Study of Acyclovir Pharmacokinetics in Obese Patients. Antimicrob Agents Chemother. 2016 Jan 11;60(3):1830-3. DOI: 10.1128/AAC.02010-15

24. Abernethy DR, Greenblatt DJ, Divoll M, Smith $\mathrm{RB}$, Shader RI. The influence of obesity on the pharmacokinetics of oral alprazolam and triazolam. Clin Pharmacokinet. 1984 MarApr;9(2):177-83. DOI: $10.2165 / 00003088$ 198409020-00005

25. Varin F, Ducharme J, Theoret Y, Besner JG, Bevan DR, Donati F. Influence of extreme obesity on the body disposition and neuromuscular blocking effect of atracurium. Clin Pharmacol Ther. 1990 Jul;48(1):18-25. DOI: 10.1038/clpt.1990.112

26. Le Jeunne C, Poirier JM, Cheymol G, Ertzbischoff O, Engel F, Hugues FC. Pharmacokinetics of intravenous bisoprolol in obese and non-obese volunteers. Eur J Clin Pharmacol. 1991;41(2):171-4. DOI: 10.1007/BF00265912

27. Abernethy DR, Todd EL, Schwartz JB. Caffeine disposition in obesity. Br J Clin Pharmacol. 1985 Jul;20(1):61-6. DOI: 10.1111/j.13652125.1985.tb02799.x

28. Caraco Y, Zylber-Katz E, Berry EM, Levy M. Carbamazepine pharmacokinetics in obese and lean subjects. Ann Pharmacother. 1995 Sep;29(9):843-7.

DOI: 10.1177/106002809502900902

29. Toma O, Suntrup P, Stefanescu A, London A, Mutch M, Kharasch E. Pharmacokinetics and tissue penetration of cefoxitin in obesity: implications for risk of surgical site infection. 
Anesth Analg. 2011 Oct;113(4):730-7. DOI: 10.1213/ANE.0b013e31821fff74

30. Bauer LA, Wareing-Tran C, Edwards WA, Raisys V, Ferreri L, Jack R, et al. Cimetidine clearance in the obese. Clin Pharmacol Ther. 1985 Apr;37(4):425-30. DOI: 10.1038/clpt.1985.66

31. Allard S, Kinzig M, Boivin G, Sorgel F, LeBel M. Intravenous ciprofloxacin disposition in obesity. Clin Pharmacol Ther. 1993 Oct;54(4):368-73. DOI: 10.1038/clpt.1993.162

32. Abernethy DR, Greenblatt DJ, Divoll M, Shader RI. Prolongation of drug half-life due to obesity: studies of desmethyldiazepam (clorazepate). J Pharm Sci. 1982 Aug;71(8):942-4. DOI: 10.1002/jps.2600710827

33. Flechner SM, Kolbeinsson ME, Tam J, Lum B. The impact of body weight on cyclosporine pharmacokinetics in renal transplant recipients. Transplantation. 1989 May;47(5):806-10. DOI: 10.1097/00007890-198905000-00012

34. Pai MP, Norenberg JP, Anderson T, Goade DW, Rodvold KA, Telepak RA, et al. Influence of morbid obesity on the single-dose pharmacokinetics of daptomycin. Antimicrob Agents Chemother. 2007 Aug;51(8):2741-7. DOI: 10.1128/AAC.00059-07

35. Cheymol G, Weissenburger J, Poirier JM, Gellee C. The pharmacokinetics of dexfenfluramine in obese and non-obese subjects. $\mathrm{Br} \mathrm{J}$ Clin Pharmacol. 1995 Jun;39(6):684-7

36. Xu B, Zhou D, Ren L, Shulman S, Zhang X, Xiong $M$. Pharmacokinetic and pharmacodynamics of intravenous dexmedetomidine in morbidly obese patients undergoing laparoscopic surgery. $\mathrm{J}$ Anesth. 2017 Dec;31(6):813-20. DOI: 10.1007/s00540017-2399-y

37. Abernethy DR, Greenblatt DJ, Smith TW. Digoxin disposition in obesity: clinical pharmacokinetic investigation. Am Heart $\mathrm{J}$. 1981 Oct;102(4):740-4. DOI: 10.1016/00028703(81)90100-9

38. Chen M, Nafziger AN, Drusano GL, Ma L, Bertino JS, Jr. Comparative pharmacokinetics and pharmacodynamic target attainment of ertapenem in normal-weight, obese, and extremely obese adults. Antimicrob Agents Chemother. 2006 Apr;50(4):1222-7. DOI: 10.1128/AAC.50.4.1222-1227.2006

39. Jaber LA, Ducharme MP, Halapy H. The effects of obesity on the pharmacokinetics and pharmacodynamics of glipizide in patients with non-insulin-dependent diabetes mellitus. Ther Drug Monit. 1996 Feb;18(1):6-13. DOI: 10.1097/00007691-199602000-00002

40. Jaber LA, Antal EJ, Slaughter RL, Welshman IR. The pharmacokinetics and pharmacodynamics of 12 weeks of glyburide therapy in obese diabetics. Eur J Clin Pharmacol. 1993;45(5):459-63. DOI: 10.1007/BF00315518

41. Abernethy DR, Greenblatt DJ. Ibuprofen disposition in obese individuals. Arthritis Rheum. 1985 Oct;28(10):1117-21. DOI: 10.1002/art.1780281006

42. Porazka J, Szalek E, Zoltaszek W, Grabowski T, Wolc A, Grzeskowiak E. Influence of obesity on pharmacokinetics and analgesic effect of ketoprofen administered intravenously to patients after laparoscopic cholecystectomy. Pharmacol Rep. 2020 Jun;72(3):763-8. DOI: 10.1007/s43440-019-00042-9

43. Natavio M, Stanczyk FZ, Molins EAG, Nelson A, Jusko WJ. Pharmacokinetics of the $1.5 \mathrm{mg}$ levonorgestrel emergency contraceptive in women with normal, obese and extremely obese body mass index. Contraception. 2019 May;99(5):306-11. DOI: 10.1016/j.contraception.2019.01.003

44. Reiss RA, Haas CE, Karki SD, Gumbiner B, Welle SL, Carson SW. Lithium pharmacokinetics in the obese. Clin Pharmacol Ther. 1994 Apr;55(4):392-8. DOI: 10.1038/clpt.1994.47

45. Abernethy DR, Greenblatt DJ. Lidocaine disposition in obesity. Am J Cardiol. 1984 Apr 1;53(8):1183-6. DOI: 10.1016/00029149(84)90659-3

46. Abernethy DR, Greenblatt DJ, Divoll M, Shader RI. Enhanced glucuronide conjugation of drugs in obesity: studies of lorazepam, oxazepam, and acetaminophen. J Lab Clin Med. 1983 Jun;101(6):873-80

47. Greenblatt DJ, Harmatz JS, Ryan MJ, Chow CR. Sustained Impairment of Lurasidone Clearance After Discontinuation of Posaconazole: Impact of Obesity, and Implications for Patient Safety. J Clin Psychopharmacol. 2018 Aug;38(4):289-95. DOI: $10.1097 / \mathrm{JCP} .0000000000000892$

48. Dunn TE, Ludwig EA, Slaughter RL, Camara DS, Jusko WJ. Pharmacokinetics and pharmacodynamics of methylprednisolone in 
obesity. Clin Pharmacol Ther. 1991 May;49(5):536-49. DOI: 10.1038/clpt.1991.64

49. Greenblatt DJ, Abernethy DR, Locniskar A, Harmatz JS, Limjuco RA, Shader RI. Effect of age, gender, and obesity on midazolam kinetics. Anesthesiology. 1984 Jul;61(1):27-35

50. Abernethy DR, Greenblatt DJ, Locniskar A, Ochs HR, Harmatz JS, Shader RI. Obesity effects on nitrazepam disposition. Br J Clin Pharmacol. 1986 Nov;22(5):551-7. DOI: 10.1111/j.1365-2125.1986.tb02934.x

51. Thorne-Humphrey LM, Goralski KB, Slayter KL, Hatchette TF, Johnston BL, McNeil SA. Oseltamivir pharmacokinetics in morbid obesity (OPTIMO trial). J Antimicrob Chemother. 2011 Sep;66(9):2083-91. DOI: 10.1093/jac/dkr257

52. Abernethy DR, Greenblatt DJ. Phenytoin disposition in obesity. Determination of loading dose. Arch Neurol. 1985 May;42(5):468-71. DOI: 10.1001/archneur.1985.04060050066010

53. Alobaid AS, Wallis SC, Jarrett P, Starr T, Stuart $\mathrm{J}$, Lassig-Smith $\mathrm{M}$, et al. Population Pharmacokinetics of Piperacillin in Nonobese, Obese, and Morbidly Obese Critically Ill Patients. Antimicrob Agents Chemother. 2017 Mar;61(3). DOI: 10.1128/AAC.01276-16

54. Milsap RL, Plaisance KI, Jusko WJ. Prednisolone disposition in obese men. Clin Pharmacol Ther. 1984 Dec;36(6):824-31. DOI: 10.1038/clpt.1984.263

55. Christoff PB, Conti DR, Naylor C, Jusko WJ. Procainamide disposition in obesity. Drug Intell Clin Pharm. 1983 Jul-Aug;17(7-8):516-22. DOI: $10.1177 / 106002808301700704$

56. Dong D, Peng X, Liu J, Qian H, Li J, Wu B. Morbid Obesity Alters Both Pharmacokinetics and Pharmacodynamics of Propofol: Dosing Recommendation for Anesthesia Induction. Drug Metab Dispos. 2016 Oct;44(10):1579-83. DOI: 10.1124/dmd.116.071605

57. Bowman SL, Hudson SA, Simpson G, Munro JF, Clements JA. A comparison of the pharmacokinetics of propranolol in obese and normal volunteers. Br J Clin Pharmacol. 1986 May;21(5):529-32. DOI: 10.1111/j.13652125.1986.tb02837.x

58. Davis RL, Quenzer RW, Bozigian HP, Warner $\mathrm{CW}$. Pharmacokinetics of ranitidine in morbidly obese women. Dicp. 1990 Nov;24(11):1040-3. DOI: $10.1177 / 106002809002401101$

59. Jung D, Mayersohn M, Perrier D, Calkins J, Saunders R. Thiopental disposition in lean and obese patients undergoing surgery.
Anesthesiology. 1982 Apr;56(4):269-74. DOI: 10.1097/00000542-198204000-00007

60. Porazka J, Szalek E, Polom W, Czajkowski M, Grabowski T, Matuszewski M, et al. Influence of Obesity and Type 2 Diabetes Mellitus on the Pharmacokinetics of Tramadol After Single Oral Dose Administration. Eur J Drug Metab Pharmacokinet. 2019 Aug;44(4):579-84. DOI: 10.1007/s13318-019-00543-1

61. Greenblatt DJ, Friedman H, Burstein ES, Scavone JM, Blyden GT, Ochs HR, et al. Trazodone kinetics: effect of age, gender, and obesity. Clin Pharmacol Ther. 1987 Aug;42(2):193-200. DOI: 10.1038/clpt.1987.132

62. Richardson J, Scheetz M, O'Donnell EP. The association of elevated trough serum vancomycin concentrations with obesity. J Infect Chemother. 2015 Jul;21(7):507-11. DOI: 10.1016/j.jiac.2015.03.007

63. Bauer LA, Black DJ, Lill JS. Vancomycin dosing in morbidly obese patients. Eur J Clin Pharmacol. 1998 Oct;54(8):621-5. DOI: $10.1007 / \mathrm{s} 002280050524$

64. Abernethy DR, Schwartz JB. Verapamil pharmacodynamics and disposition in obese hypertensive patients. J Cardiovasc Pharmacol. 1988 Feb;11(2):209-15

65. Greenblatt DJ, Harmatz JS, Chow CR. Vortioxetine Disposition in Obesity: Potential Implications for Patient Safety. J Clin Psychopharmacol. 2018 Jun;38(3):172-9. DOI: 10.1097/JCP.0000000000000861

66. Bruno CD, Harmatz JS, Duan SX, Zhang Q, Chow CR, Greenblatt DJ. Effect of lipophilicity on drug distribution and elimination: Influence of obesity. Br J Clin Pharmacol. 2021 Jan 15. DOI: 10.1111/bcp.14735

67. Maudens KE, Patteet L, van Nuijs AL, Van Broekhoven C, Covaci A, Neels H. The influence of the body mass index (BMI) on the volume of distribution of ethanol. Forensic Sci Int. $2014 \quad$ Oct;243:74-8. DOI: 10.1016/j.forsciint.2014.04.036

68. Kalitsky-Szirtes J, Shayeganpour A, Brocks DR, Piquette-Miller M. Suppression of drugmetabolizing enzymes and efflux transporters in the intestine of endotoxin-treated rats. Drug Metab Dispos. 2004 Jan;32(1):20-7. DOI: 10.1124/dmd.32.1.2032/1/20 [pii]

69. Piquette-Miller M, Pak A, Kim H, Anari R, Shahzamani A. Decreased expression and activity of P-glycoprotein in rat liver during 
acute inflammation. Pharm Res. 1998 May;15(5):706-11

70. Aitken AE, Morgan ET. Gene-specific effects of inflammatory cytokines on cytochrome $\mathrm{P} 450$ 2C, 2 B6 and 3A4 mRNA levels in human hepatocytes. Drug Metab Dispos. 2007 Sep;35(9):1687-93. DOI: dmd.107.015511 [pii]10.1124/dmd.107.015511

71. Vee ML, Lecureur V, Stieger B, Fardel O. Regulation of drug transporter expression in human hepatocytes exposed to the proinflammatory cytokines tumor necrosis factor-alpha or interleukin-6. Drug Metab Dispos. 2009 Mar;37(3):685-93. DOI: dmd.108.023630 [pii]

10.1124/dmd.108.023630

72. Cherrington NJ, Slitt AL, Li N, Klaassen CD. Lipopolysaccharide-mediated regulation of hepatic transporter mRNA levels in rats. Drug Metab Dispos. 2004 Jul;32(7):734-41. DOI: 32/7/734 [pii]

73. Shedlofsky SI, Israel BC, McClain CJ, Hill DB, Blouin RA. Endotoxin administration to humans inhibits hepatic cytochrome P450mediated drug metabolism. J Clin Invest. 1994 Dec;94(6):2209-14. DOI: 10.1172/JCI117582

74. Patel JP, Brocks DR. The effect of oral lipids and circulating lipoproteins on the metabolism of drugs. Expert Opin Drug Metab Toxicol. $2009 \quad$ Nov;5(11):1385-98. DOI: 10.1517/17425250903176439

75. Barras M, Legg A. Drug dosing in obese adults. Aust Prescr. 2017 Oct;40(5):189-93. DOI: 10.18773/austprescr.2017.053

76. Han PY, Duffull SB, Kirkpatrick CM, Green B. Dosing in obesity: a simple solution to a big problem. Clin Pharmacol Ther. 2007 Nov;82(5):505-8. DOI: 10.1038/sj.clpt.6100381

77. Harskamp-van Ginkel MW, Hill KD, Becker KC, Testoni D, Cohen-Wolkowiez M, Gonzalez $\mathrm{D}$, et al. Drug Dosing and Pharmacokinetics in Children With Obesity: A Systematic Review. JAMA Pediatr. 2015 Jul;169(7):678-85. DOI: 10.1001/jamapediatrics.2015.132

78. Mahmood I. Prediction of clearance and volume of distribution in the obese from normal weight subjects: an allometric approach. Clin Pharmacokinet. 2012 Aug 1;51(8):527-42. DOI: 10.2165/11631630-000000000-00000

79. Fareed J, Hoppensteadt D, Walenga J, Iqbal O, Ma Q, Jeske W, et al. Pharmacodynamic and pharmacokinetic properties of enoxaparin : implications for clinical practice. Clin Pharmacokinet. 2003;42(12):1043-57. DOI: 10.2165/00003088-200342120-00003

80. Pang KS, Gillette JR. Sequential first-pass elimination of a metabolite derived from a precursor. J Pharmacokinet Biopharm. 1979 Jun;7(3):275-90

81. Panchal SK, Brown L. Rodent models for metabolic syndrome research. J Biomed Biotechnol. 2011;2011:351982. DOI: 10.1155/2011/351982

82. Russell JC, Graham S, Hameed M. Abnormal insulin and glucose metabolism in the JCR:LAcorpulent rat. Metabolism. 1994 May;43(5):538-43. DOI: 10.1016/00260495(94)90192-9

83. Tomankova V, Liskova B, Skalova L, Bartikova $\mathrm{H}$, Bousova I, Jourova L, et al. Altered cytochrome $\mathrm{P} 450$ activities and expression levels in the liver and intestines of the monosodium glutamate-induced mouse model of human obesity. Life Sci. 2015 Jul 15;133:1520. DOI: 10.1016/j.lfs.2015.04.014

84. Behan JW, Avramis VI, Yun JP, Louie SG, Mittelman SD. Diet-induced obesity alters vincristine pharmacokinetics in blood and tissues of mice. Pharmacol Res. 2010 May;61(5):385-90. DOI: 10.1016/j.phrs.2010.01.007

85. Jang EH, Kim HK, Park CS, Kang JH. Increased expression of hepatic organic cation transporter 1 and hepatic distribution of metformin in highfat diet-induced obese mice. Drug Metab Pharmacokinet. 2010;25(4):392-7. DOI: 10.2133/dmpk.dmpk-10-nt-010

86. Veniant MM, Komorowski R, Chen $\mathrm{P}$, Stanislaus S, Winters K, Hager T, et al. Longacting FGF21 has enhanced efficacy in dietinduced obese mice and in obese rhesus monkeys. $\quad$ Endocrinology. 2012 Sep;153(9):4192-203. DOI: 10.1210/en.20121211

87. Ning M, Jeong H. High-Fat Diet Feeding Alters Expression of Hepatic Drug-Metabolizing Enzymes in Mice. Drug Metab Dispos. 2017 Jul;45(7):707-11. DOI: 10.1124/dmd.117.075655

88. Klaus S, Pultz S, Thone-Reineke C, Wolfram S. Epigallocatechin gallate attenuates diet-induced obesity in mice by decreasing energy absorption and increasing fat oxidation. Int $\mathrm{J}$ Obes (Lond). 2005 Jun;29(6):615-23. DOI: 10.1038/sj.ijo.0802926 
89. Ghose R, Omoluabi O, Gandhi A, Shah P, Strohacker K, Carpenter KC, et al. Role of highfat diet in regulation of gene expression of drug metabolizing enzymes and transporters. Life Sci. 2011 Jul 4;89(1-2):57-64. DOI: 10.1016/j.lfs.2011.05.005

90. Xie W, Gu D, Li J, Cui K, Zhang Y. Effects and action mechanisms of berberine and Rhizoma coptidis on gut microbes and obesity in high-fat diet-fed C57BL/6J mice. PLoS One. 2011;6(9):e24520. DOI: 10.1371/journal.pone.0024520

91. Maximos S, Chamoun M, Gravel S, Turgeon J, Michaud V. Tissue Specific Modulation of cyp2c and cyp3a mRNA Levels and Activities by Diet-Induced Obesity in Mice: The Impact of Type 2 Diabetes on Drug Metabolizing Enzymes in Liver and Extra-Hepatic Tissues. Pharmaceutics. 2017 Sep 26;9(4). DOI: 10.3390/pharmaceutics 9040040

92. Fu L, Bruckbauer A, Li F, Cao Q, Cui X, Wu R, et al. Leucine amplifies the effects of metformin on insulin sensitivity and glycemic control in diet-induced obese mice. Metabolism. 2015 Jul;64(7):845-56.

DOI: 10.1016/j.metabol.2015.03.007

93. Hsu YJ, Lee MC, Huang CC, Ho CS. The effects of different types of aquatic exercise training interventions on a high-fructose dietfed mice. Int J Med Sci. 2021;18(3):695-705. DOI: $10.7150 /$ ijms. 52347

94. Hohos NM, Elliott EM, Giornazi A, Silva E, Rice JD, Skaznik-Wikiel ME. High-fat diet induces an ovulatory defect associated with dysregulated endothelin-2 in mice. Reproduction. 2021 Mar;161(3):307-17. DOI: 10.1530/REP-20-0290

95. Bousova I, Matouskova $\mathrm{P}$, Bartikova $\mathrm{H}$, Szotakova B, Hanusova V, Tomankova V, et al. Influence of diet supplementation with green tea extract on drug-metabolizing enzymes in a mouse model of monosodium glutamateinduced obesity. Eur J Nutr. 2016 Feb;55(1):361-71. DOI: 10.1007/s00394-0150856-7

96. Al Nebaihi HM, Al Batran R, Ussher JR, Maayah ZH, El-Kadi AOS, Brocks DR. Dietary-Induced Obesity, Hepatic Cytochrome P450, and Lidocaine Metabolism: Comparative Effects of High-Fat Diets in Mice and Rats and Reversibility of Effects With Normalization of Diet. J Pharm Sci. 2020 Feb;109(2):1199-210. DOI: $10.1016 / j . x p h s .2019 .11 .007$
97. Abdussalam A, Al-Agili M, Al Nebaihi HM, Mayo PR, Gabr RQ, Brocks DR. DietaryInduced Obesity and Changes in the Biodistribution and Metabolism of Amiodarone in the Rat. J Pharm Sci. 2018 Nov;107(11):2938-45.

DOI: 10.1016/j.xphs.2018.06.032

98. Bin Jardan YA, Abdussalam A, El-Kadi AOS, Brocks DR. Dronedarone: the effect of dietinduced obesity on its metabolism and experimental hyperlipidemia on its metabolism and tissue distribution in the rat. Can J Physiol Pharmacol. 2020 Mar;98(3):177-81. DOI: 10.1139/cjpp-2019-0125

99. Abdussalam A, Elshenawy OH, Bin Jardan YA, El-Kadi AOS, Brocks DR. The Obesogenic Potency of Various High-Caloric Diet Compositions in Male Rats, and Their Effects on Expression of Liver and Kidney Proteins Involved in Drug Elimination. J Pharm Sci. 2017 Jun;106(6):1650-8. DOI: 10.1016/j.xphs.2017.02.002

100. Raucy JL, Lasker JM, Kraner JC, Salazar DE, Lieber CS, Corcoran GB. Induction of cytochrome P450IIE1 in the obese overfed rat. Mol Pharmacol. 1991 Mar;39(3):275-80

101. Kobuchi S, Fukushima K, Aoyama H, Ito Y, Sugioka N, Takada K. Effects of obesity induced by high-fat diet on the pharmacokinetics of atazanavir in rats. Drug Metab Lett. 2013 Mar;7(1):39-46. DOI: 10.2174/18723128112066660016

102. Wong BK, U SW, Corcoran GB. An overfed rat model that reproduces acetaminophen disposition in obese humans. Drug Metab Dispos. 1986 Nov-Dec;14(6):674-9

103. Shum L, Jusko WJ. Theophylline disposition in obese rats. J Pharmacol Exp Ther. 1984 Feb;228(2):380-6

104. Ghoneim RH, Ngo Sock ET, Lavoie JM, Piquette-Miller M. Effect of a high-fat diet on the hepatic expression of nuclear receptors and their target genes: relevance to drug disposition. Br J Nutr. 2015 Feb 14;113(3):507-16. DOI: 10.1017/S0007114514003717

105. Zhang L, Xu P, Cheng Y, Wang P, Ma X, Liu $M$, et al. Diet-induced obese alters the expression and function of hepatic drugmetabolizing enzymes and transporters in rats. Biochem Pharmacol. 2019 Jun;164:368-76. DOI: 10.1016/j.bcp.2019.05.002

106. Corcoran GB, Wong BK. Obesity as a risk factor in drug-induced organ injury: increased 
liver and kidney damage by acetaminophen in the obese overfed rat. J Pharmacol Exp Ther. 1987 Jun;241(3):921-7

107. Zannikos PN, Bandyopadhyay AM, Robertson LW, Blouin RA. Effect of nutritional obesity on the induction of CYP2B enzymes following phenobarbital treatment. Drug Metab Dispos. 1993 Sep-Oct;21(5):782-7

108. Khemawoot P, Yokogawa K, Shimada T, Miyamoto K. Obesity-induced increase of CYP2E1 activity and its effect on disposition kinetics of chlorzoxazone in Zucker rats. Biochem Pharmacol. 2007 Jan 1;73(1):155-62. DOI: 10.1016/j.bcp.2006.09.006

109. Picklo MJ, Sr., Idso JP, Jackson MI. SGlutathionylation of hepatic and visceral adipose proteins decreases in obese rats. Obesity (Silver Spring). 2013 Feb;21(2):297-305. DOI: 10.1002/oby.20002

110. Jiang S, Yan K, Sun B, Gao S, Yang X, Ni Y, et al. Long-Term High-Fat Diet Decreases Hepatic Iron Storage Associated with Suppressing TFR2 and ZIP14 Expression in Rats. J Agric Food Chem. 2018 Nov 7;66(44):11612-21. DOI: 10.1021/acs.jafc.8b02974

111. Tranberg B, Hellgren LI, Lykkesfeldt J, Hansen AK. High-fat feeding induces mobilization of vitamin C in obese prone rats. Res Vet Sci. 2018 Aug;119:167-9.

DOI: 10.1016/j.rvsc.2018.06.011

112. El-Sherbiny M, Eldosoky M, El-Shafey M, Othman G, Elkattawy HA, Bedir T, et al. Vitamin D nanoemulsion enhances hepatoprotective effect of conventional vitamin $\mathrm{D}$ in rats fed with a high-fat diet. Chem Biol Interact. 2018 May 25;288:65-75. DOI: 10.1016/j.cbi.2018.04.010

113. Crew RC, Waddell BJ, Mark PJ. Obesityinduced changes in hepatic and placental clock gene networks in rat pregnancy. Biol Reprod. 2018 Jan 1;98(1):75-88. DOI: 10.1093/biolre/iox 158

114. Bertinato J, Aroche C, Plouffe LJ, Lee M, Murtaza Z, Kenney L, et al. Diet-induced obese rats have higher iron requirements and are more vulnerable to iron deficiency. Eur J Nutr. 2014 Apr;53(3):885-95. DOI: 10.1007/s00394-0130592-9

115. Corcoran GB, Wong BK, Shum L, Galinsky RE. Acetaminophen sulfation deficit in obese rats overfed an energy-dense cafeteria diet. Endocr Res. $\quad 1987 ; 13(2): 101-21 . \quad$ DOI: $10.3109 / 07435808709023667$
116. Sugioka N, Haraya K, Fukushima K, Ito Y, Takada K. Effects of obesity induced by highfat diet on the pharmacokinetics of nelfinavir, a HIV protease inhibitor, in laboratory rats. Biopharm Drug Dispos. 2009 Dec;30(9):53241. DOI: $10.1002 /$ bdd. 689

117. Goodman ZD. The impact of obesity on liver histology. Clin Liver Dis. 2014 Feb;18(1):3340. DOI: $10.1016 /$ j.cld.2013.09.010

118. Kumru OS, Wang Y, Gombotz CWR, KelleyClarke B, Cieplak W, Kim T, et al. Physical Characterization and Stabilization of a Lentiviral Vector Against Adsorption and Freeze-Thaw. J Pharm Sci. 2018 Nov;107(11):2764-74. DOI: 10.1016/j.xphs.2018.07.010

119. Zha J, Zhang Q, Li M, Wang JR, Mei X. Improving Dissolution Properties by Polymers and Surfactants: A Case Study of Celastrol. J Pharm Sci. 2018 Nov;107(11):2860-8. DOI: 10.1016/j.xphs.2018.07.008

120. Zannikos PN, Bandyopadhyay AM, Robertson LW, Blouin RA. Expression of the CYP3A and CYP2C11 enzymes in a nutritionally obese rodent model: response to phenobarbital treatment. Int J Obes Relat Metab Disord. 1994 Jun;18(6):369-74

121. Aksenov IV, Avren'eva LI, Guseva GV, Trusov $\mathrm{NV}$, Balakina AS, Mzhel'skaya KV, et al. [Effects of quercetin on protective capacity in rats fed a high-fructose diet]. Vopr Pitan. 2018;87(5):6-12. DOI: 10.24411/0042-88332018-10047

122. Sawamoto K, Huong TT, Sugimoto N, Mizutani Y, Sai Y, Miyamoto K. Mechanisms of lower maintenance dose of tacrolimus in obese patients. Drug Metab Pharmacokinet. 2014;29(4):341-7. DOI: 10.2133/dmpk.dmpk$13-\mathrm{rg}-110$

123. Irizar A, Barnett CR, Flatt PR, Ioannides C. Defective expression of cytochrome P450 proteins in the liver of the genetically obese Zucker rat. Eur J Pharmacol. 1995 Dec 7;293(4):385-93. DOI: 10.1016/09266917(95)90059-4

124. Sadler NC, Webb-Robertson BM, Clauss TR, Pounds JG, Corley R, Wright AT. High-Fat Diets Alter the Modulatory Effects of Xenobiotics on Cytochrome P450 Activities. Chem Res Toxicol. 2018 May 21;31(5):308-18. DOI: $10.1021 /$ acs.chemrestox.8b00008

125. Wang M, Tian X, Leung L, Wang J, Houvig N, Xiang J, et al. Comparative pharmacokinetics 
and metabolism studies in lean and diet-induced obese mice: an animal efficacy model for 11 beta-hydroxysteroid dehydrogenase type 1 (11beta-HSD1) inhibitors. Drug Metab Lett. 2011 Jan;5(1):55-63. DOI: $10.2174 / 187231211794455280$

126. Kudo T, Toda T, Ushiki T, Ohi K, Ikarashi N, Ochiai $\mathrm{W}$, et al. Differences in the pharmacokinetics of Cyp3a substrates in TSOD and streptozotocin-induced diabetic mice. Xenobiotica. 2010 Apr;40(4):282-90. DOI: 10.3109/00498251003596809

127. Watson AM, Poloyac SM, Howard G, Blouin RA. Effect of leptin on cytochrome P-450, conjugation, and antioxidant enzymes in the ob/ob mouse. Drug Metab Dispos. 1999 Jun;27(6):695-700

128. Patoine D, Levac X, Pilote S, Drolet B, Simard C. Decreased CYP3A expression and activity in guinea pig models of diet-induced metabolic syndrome: is fatty liver infiltration involved? Drug Metab Dispos. 2013 May;41(5):952-7. DOI: 10.1124/dmd.112.050641

129. Matsumoto RM, Jusko WJ, Corcoran GB. Hepatic cytochrome P-450 and in vitro drug metabolism in an overfed rat model of obesity. Drug Nutr Interact. 1988;5(4):236-47

130. Brocks DR, Hamdy DA, Ben-Eltriki M, Patel JP, AO SE-K. Effect of rat serum lipoproteins on mRNA levels and amiodarone metabolism by cultured primary rat hepatocytes. J Pharm Sci. $2013 \quad$ Jan;102(1):262-70. DOI: 10.1002/jps. 23348

131. Patel JP, Hamdy DA, El-Kadi AO, Brocks DR. Effect of serum lipoproteins on stereoselective halofantrine metabolism by rat hepatocytes. Chirality. 2012 Jul;24(7):558-65. DOI: 10.1002/chir.22054

132. Fisher CD, Lickteig AJ, Augustine LM, RangerMoore J, Jackson JP, Ferguson SS, et al. Hepatic cytochrome $\mathrm{P} 450$ enzyme alterations in humans with progressive stages of nonalcoholic fatty liver disease. Drug Metab Dispos. 2009 Oct;37(10):2087-94.

DOI: 10.1124/dmd.109.027466

133. Cottier K, Le X, Heyward S, editors. The use of primary cryopreserved human hepatocytes as a model for non-alcoholic fatty liver disease (NAFLD) related changes in phase I and phase II enzyme activities. International Society for the Study of Xenobiotics 12th Annual International meeting; 2019 July 28-31; Portland, OR2019.
134. Cobbina E, Akhlaghi F. Non-alcoholic fatty liver disease (NAFLD) - pathogenesis, classification, and effect on drug metabolizing enzymes and transporters. Drug Metab Rev. 2017 May;49(2):197-211. DOI: 10.1080/03602532.2017.1293683

135. Zarezadeh M, Saedisomeolia A, Shekarabi M, Khorshidi M, Emami MR, Muller DJ. The effect of obesity, macronutrients, fasting and nutritional status on drug-metabolizing cytochrome P450s: a systematic review of current evidence on human studies. Eur J Nutr. 2020 Nov 3. DOI: 10.1007/s00394-020-02421$\mathrm{y}$

136. Todd EL, Abernethy DR. Pharmacokinetics and dynamics of (+/-)-verapamil in lean and obese Zucker rats. J Pharmacol Exp Ther. 1986 Aug;238(2):642-7

137. Shum L, Jusko WJ. Verofylline pharmacokinetics in dietary-induced obese rats: role of fat mass and protein binding in determining volume of distribution. Xenobiotica. 1991 Nov;21(11):1419-30. DOI: 10.3109/00498259109044392

138. Elsherbiny ME, El-Kadi AO, Brocks DR. The metabolism of amiodarone by various CYP isoenzymes of human and rat, and the inhibitory influence of ketoconazole. J Pharm Pharm Sci. 2008;11(1):147-59

139. Primrose M, Al Nebaihi H, Brocks DR, Widder S, Fairey A, Tsui B, et al. Rectus sheath singleinjection blocks: a study to quantify local anaesthetic absorption using serial ultrasound measurements and lidocaine serum concentrations. J Pharm Pharmacol. 2019 Aug;71(8):1282-90. DOI: 10.1111/jphp.13110

140. Lemley CO, Butler ST, Butler WR, Wilson ME. Short communication: insulin alters hepatic progesterone catabolic enzymes cytochrome P450 2C and 3A in dairy cows. J Dairy Sci. 2008 Feb;91(2):641-5. DOI: 10.3168/jds.2007-0636

141. Nichols AI, D'Ambrosio R, Pyszczynski NA, Jusko WJ. Pharmacokinetics and pharmacodynamics of prednisolone in obese rats. J Pharmacol Exp Ther. 1989 Sep;250(3):963-70

142. Alexander JK, Dennis EW, Smith WG, Amad KH, Duncan WC, Austin RC. Blood volume, cardiac output, and distribution of systemic blood flow in extreme obesity. Cardiovasc Res Cent Bull. 1962 Winter;1:39-44 
143. Hall JE. The kidney, hypertension, and obesity. Hypertension. 2003 Mar;41(3 Pt 2):625-33. DOI: 10.1161/01.HYP.0000052314.95497.78

144. Hall JE, do Carmo JM, da Silva AA, Wang Z, Hall ME. Obesity, kidney dysfunction and hypertension: mechanistic links. Nat Rev Nephrol. 2019 Jun;15(6):367-85. DOI: 10.1038/s41581-019-0145-4

145. Carroll JF, Huang M, Hester RL, Cockrell K, Mizelle HL. Hemodynamic alterations in hypertensive obese rabbits. Hypertension. 1995 Sep;26(3):465-70.

DOI: 10.1161/01.hyp.26.3.465

146. Belotta AF, Teixeira CR, Padovani CR, Rahal SC, Mayer MN, Mamprim MJ. Sonographic Evaluation of Liver Hemodynamic Indices in Overweight and Obese Dogs. J Vet Intern Med. 2018 Jan;32(1):181-7. DOI: 10.1111 jvim. 14883

147. Subramanian M, Kurawattimath V, Pocha K, Freeden C, Rao I, Mariappan TT, et al. Role of hepatic blood flow and metabolism in the pharmacokinetics of ten drugs in lean, aged and obese rats. Xenobiotica. 2014 Dec;44(12):110816. DOI: $10.3109 / 00498254.2014 .932470$

148. Mancini FP, Lanni A, Sabatino L, Moreno M, Giannino A, Contaldo F, et al. Fenofibrate prevents and reduces body weight gain and adiposity in diet-induced obese rats. FEBS Lett. 2001 Feb 23;491(1-2):154-8. DOI: 10.1016/s0014-5793(01)02146-9

149. Lasker S, Rahman MM, Parvez F, Zamila M, Miah P, Nahar K, et al. High-fat diet-induced metabolic syndrome and oxidative stress in obese rats are ameliorated by yogurt supplementation. Sci Rep. 2019 Dec 27;9(1):20026. DOI: 10.1038/s41598-01956538-0

150. Grant H, Zhang Z, Li L, Wang Y, Kawamoto S, Pénisson S, et al. Larger organ size caused by obesity is a mechanism for higher cancer risk. BioRxiv. 2020:1-23. DOI: https://doi.org/10.1101/2020.07.27.223529

151. Hall JE, Brands MW, Dixon WN, Smith MJ, Jr. Obesity-induced hypertension. Renal function and systemic hemodynamics. Hypertension. 1993 Sep;22(3):292-9. DOI: 10.1161/01.hyp.22.3.292

152. Altunkaynak BZ, Ozbek E. Overweight and structural alterations of the liver in female rats fed a high-fat diet: a stereological and histological study. Turk J Gastroenterol. 2009 Jun;20(2):93-103
153. Mehvar R. Application of Organ Clearance to Estimation of the In Vivo Hepatic Extraction Ratio. Curr Clin Pharmacol. 2016;11(1):47-52. DOI: $10.2174 / 1574884710666150817104746$

154. Davies B, Morris T. Physiological parameters in laboratory animals and humans. Pharm Res. $1993 \mathrm{Jul} ; 10(7): 1093-5$

155. Ijaz S, Yang W, Winslet MC, Seifalian AM. Impairment of hepatic microcirculation in fatty liver. Microcirculation. 2003 Dec;10(6):447-56. DOI: $10.1038 /$ sj.mn.7800206

156. Padwal RS, Gabr RQ, Sharma AM, Langkaas LA, Birch DW, Karmali S, et al. Effect of gastric bypass surgery on the absorption and bioavailability of metformin. Diabetes Care. 2011 Jun;34(6):1295-300. DOI: dc10-2140 [pii]10.2337/dc10-2140

157. Wongchitrat $\mathrm{P}$, Klosen $\mathrm{P}$, Pannengpetch $\mathrm{S}$, Kitidee K, Govitrapong $\mathrm{P}$, Isarankura-NaAyudhya C. High-fat diet-induced plasma protein and liver changes in obese rats can be attenuated by melatonin supplementation. Nutr Res. $2017 \quad$ Jun;42:51-63. DOI: 10.1016/j.nutres.2017.04.011

158. Wiese MD, Meakin AS, Varcoe TJ, Darby JRT, Sarr O, Kiser P, et al. Hepatic cytochrome P450 function is reduced by life-long Western diet consumption in guinea pig independent of birth weight. Life Sci. 2021 Dec 15;287. DOI: Artn 12013310.1016/J.Lfs.2021.120133 